\title{
Morphometric Analysis of Coptotermes spp. Soldier Caste (Blattodea: Rhinotermitidae) in Indonesia and Evidence of Coptotermes gestroi Extreme Head-Capsule Shapes
}

\author{
Bramantyo Wikantyoso ${ }^{1,2, *}$, Shu-Ping Tseng ${ }^{3}$, Setiawan Khoirul Himmi ${ }^{2}$, Sulaeman Yusuf ${ }^{2}$ (D) \\ and Tsuyoshi Yoshimura ${ }^{1}$ \\ 1 Research Institute for Sustainable Humanosphere (RISH), Kyoto University, Gokasho, Uji, \\ Kyoto 611-0011, Japan; tsuyoshi@rish.kyoto-u.ac.jp \\ 2 Research Center for Biomaterials, Indonesian Institute of Sciences (LIPI) Jl. Raya Bogor km 46 Cibinong, \\ Bogor 16911, Indonesia; khoirul_himmi@biomaterial.lipi.go.id (S.K.H.); sulaeman@biomaterial.lipi.go.id (S.Y.) \\ 3 Department of Entomology, University of California, 900 University Avenue, Riverside, CA 92521, USA; \\ shupingt@ucr.edu \\ * Correspondence: wikantyoso_bramantyo@rish.kyoto-u.ac.jp
}

\section{check for} updates

Citation: Wikantyoso, B.; Tseng, S.-P.; Himmi, S.K.; Yusuf, S.; Yoshimura, T.

Morphometric Analysis of Coptotermes spp. Soldier Caste (Blattodea: Rhinotermitidae) in Indonesia and Evidence of Coptotermes gestroi Extreme Head-Capsule Shapes. Insects 2021, 12, 477. https://doi.org/10.3390/ insects12050477

Academic Editor: Michael Rust

Received: 6 April 2021

Accepted: 17 May 2021

Published: 20 May 2021

Publisher's Note: MDPI stays neutral with regard to jurisdictional claims in published maps and institutional affiliations.

Copyright: (c) 2021 by the authors Licensee MDPI, Basel, Switzerland. This article is an open access article distributed under the terms and conditions of the Creative Commons Attribution (CC BY) license (https:/ / creativecommons.org/licenses/by/ $4.0 /)$.
Simple Summary: The morphological characteristics of the soldier caste in termites provide valuable taxonomic information at the species level. Head-shape variation in soldiers was often used as an indicative characteristic in some genera. While species with egg-shaped and waterdrop-shaped head capsule (HC), Coptotermes gestroi and C. curvignathus, respectively, are familiar in Indonesia, neither a measurement nor head index may avoid the subjectivity of shape interpretation. We conducted linear and geometric morphometrics analyses of soldiers' HC of Coptotermes spp. obtained from various locations in Indonesia. Although subtle differences were observed, the posterior parts of the HC laterally expanded in a gradual manner in C. gestroi, C. sepangensis, and C. curvignathus in that order. Furthermore, three extreme head-shape variations of $C$. gestroi were found to exist in nature. Overall, we explicitly vocalized the complexity of utilizing HC morphometric measurement and shape for species determination in Coptotermes spp.

Abstract: Linear and geometric morphometrics approaches were conducted to analyze the head capsule (HC) shape of collected soldier caste specimens of Coptotermes from various locations in Indonesia. The soldiers' morphology was observed and measured. The results of the principal component analysis of the group of all species showed two important groups of variables, i.e., the body size and setae characteristics of the pronotum and head. The multicollinearity of the morphometric variables showed the importance of body measurements as well as important alternative characteristics such as the pronotum setae $(\mathrm{PrS})$ and $\mathrm{HC}$ setae. Four trends of $\mathrm{HC}$ shape were observed across the species. Interestingly, three extreme shapes were depicted by geometric morphometrics of the C. gestroi HC. The phylogenetic tree inferred from $12 \mathrm{~S}$ and $16 \mathrm{~S}$ mitochondrial gene fragments showed high confidence for $C$. gestroi populations. The lateral expansion of the posterior part of the $\mathrm{HC}$ across the species was in accordance with the increasing of the number of hairlike setae on the pronotum and HC. These differences among species might be associated with mandible-force-related defensive labor and sensitivity to environmental stressors.

Keywords: morphometry; geometric morphometrics; head capsule shape; postmentum waist; pronotum setae; Coptotermes gestroi; Coptotermes curvignathus; Coptotermes elisae

\section{Introduction}

Termites live in a variety of ecosystems and are widely distributed in tropical as well as subtropical regions, and low- and high-altitude montane forests, and they also infiltrate urbanized zones [1,2]. Coptotermes (Wasmann) were popularly related to anthropogenic 
settlement; they attack many kinds of commercial logs [3-7]. Coptotermes gestroi is known as an "urban pest termite" in tropical Southeast Asia; C. elisae, C. curvignathus, and C. kalshoveni are popular as "living trees pest termites" in Sumatra and Papua New Guinea's plantation areas and dipterocarp forests; and C. sepangensis attacks suburban and rural areas in Malaysia [8-14]. Recently, C. gestroi behavior was observed attacking harvested and readily packed mangoes (Mangifera indica L.), which is unusual behavior for termites [15]. Despite their taxonomical complexity, all the aforementioned species are known to be well-distributed as termite pests in the realm of Malesiana.

The characteristics of termite soldiers' sclerotized head capsule (hereinafter abbreviated to $\mathrm{HC}$ ) provide valuable taxonomic information at the species level and have also helped to resolve the synonym issue [16-18]. However, it was reported that the HC size and shape were affected by the development of the frontal gland and muscle during soldier differentiation $[19,20]$. The variations of the head shape in soldiers were usually drawn dorsally or laterally and have been used as an indicative characteristic in some genera. For instance, an egg-shaped head is a familiar characteristic of $C$. gestroi [21], while a waterdrop-shaped head is known to be a characteristic of $C$. curvignathus, particularly in Indonesia. On the other hand, Kirton and Brown [22] were aware of the problems inherent in employing linear morphometric values in species delimitation. Hence, by collecting a considerable amount of HC morphometric data, they argued that both $C$. havilandi and $C$. javanicus were synonyms of $C$. gestroi. They also argued that $C$. travians, identified in several published studies [23-27], was a misidentification of $C$. gestroi due to the use of continuous variations. In Odontotermes, Reticulitermes, and Heterotermes, however, other characteristics' variations such as setae positions and numbers were found to be important and specifically different [28-32].

Although several HC measurement records exist [9,16,25,33-35], neither a single measurement nor a head index has been used to represent shape. Hence, the difficulty in characterizing the $\mathrm{HC}$ shape has been a problem for some time. In practice, determining differences among shapes by visual evaluation is subjective, and so this criterion is difficult to apply [36]. While subjectivity cannot be completely eliminated, shape should be inferred in a specific way and should be based on the geometric shape, physical properties, or chemical composition corresponding to a biological function, environmental pressure, genes, or biomaterial fabrication $[37,38]$.

In this study, the differences in the morphology of soldier caste of Coptotermes spp. from Indonesia were evaluated. We collected Coptotermes spp. from several sampling areas in Indonesia and analyzed the HC and other parts' morphometrics using multivariate analysis [39-41]. Linear morphometric variations in Coptotermes spp., particularly C. gestroi, were exposed. We were the first to make use of geometric morphometrics of the soldiers' HC and postmentum (hereinafter abbreviated to PS) in Coptotermes spp. We conducted a landmark-based analysis to elucidate the variation of shapes by focusing on a specific anatomical point on a Cartesian plane [42-47]. Since genetic information of Coptotermes spp. in Indonesia was limited [10,40,48,49], we inferred phylogenetic analysis from mitochondrial gene fragments to add important data for the genetic diversity.

\section{Materials and Methods}

\subsection{Specimen Collection and Identification}

Specimens were collected from nine locations in Indonesia from 2017-2019: around Sumatra Island (Simeulue Island, Karimunbesar Island, and Batam Island); Java Island from West Java province (Gunung Sindur, Cipinang, Cibinong, Karadenan, Parungpanjang) and the Special Capital Region of Jakarta (Pondok Kelapa); and Papua Island (Asmat Regency). Termites were preserved in 70\% ethanol. Observations and photographs of the specimens were made using a digital microscope (VHX-5000, Keyence Corp., Osaka, Japan). Picture tracing was conducted using Drawing Pad (XP Pen Deco 2, Shenzhen, China) in Autodesk Sketchbook version 8.7.1. A total of 228 specimens of termite soldiers were measured (66 C. curvignathus, 10 C. elisae, 84 C. gestroi, 63 C. sepangensis, and 5 C. kalshoveni 
specimens). The identification was undertaken by collecting many characteristics from each specimen and matching them with references [16,22-26,50-53]. The Indonesian specimens were deposited at the Museum Zoologicum Bogoriense and Research Center for Biomaterials-Indonesian Institute of Sciences (LIPI), Cibinong, Indonesia. All Japan specimens belong to the Research Institute for Sustainable Humanosphere (RISH)-Kyoto University, Kyoto, Japan.

\subsection{Linear Morphometric Analysis}

Linear morphometric values were obtained from the distance between homologous points or landmarks of a set of particular landmarks (Figure 1) [54]. A total of 78 characteristics were collected in the initial observation of the specimens, and 34 of these were quantitative characteristics (Table S1) [30,55-58]. The characteristics were not subjected to the same statistical analysis if they were correlated with each other.

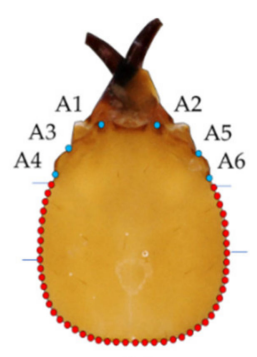

(a).

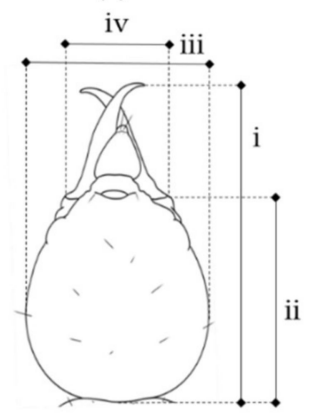

(d).

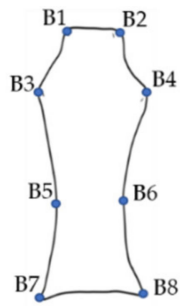

(b).

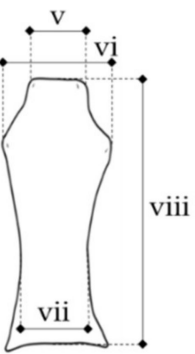

(e).

A1 \& A2: Landmark of lateral fronto clypeus base A3 \& A5: Landmark of protruding antennal socket front A4 \& A6: Landmark of protruding antennal socket rear B1 \& B2: Landmark of anterior margin corner

B3 \& B4: Landmark of the widest point

B5 \& B6: Landmark of the narrowest point

B7 \& B8: Landmark of posterior margin corner

C1: Landmark of posterior margin

C2: Landmark of anterior margin

- : Landmark

- : Semi-landmark

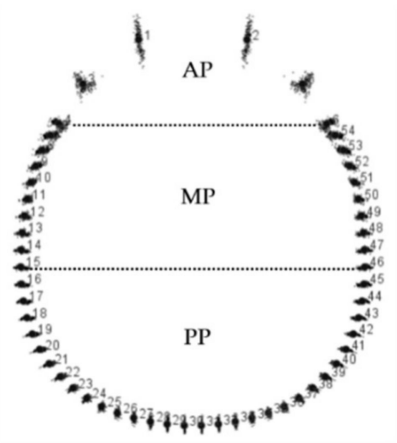

(c).

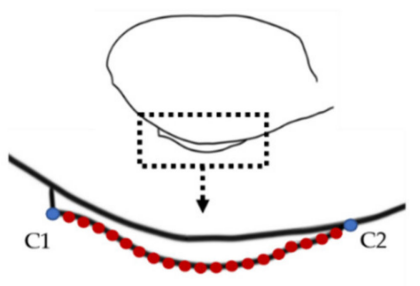

(f).

i: Head length to the tip mandible ii: Head length to the base mandible iii: Head width

iv: Head width on the base mandible

v: Postmentum anterior width

vi: Postmentum maximum width

vii: Postmentum minimum width

viii: Postmentum median length

AP: Anterior Part

MP: Medial Part

PP: Posterior Part

Figure 1. The landmark collection in: (a) head capsule; (b) ventral view postmentum; (f) lateral view postmentum. Linear morphometric measurement collection in: (d) head capsule; (e) postmentum. (c) The head capsule was randomly divided into three parts by an imaginary line on two pairs of landmarks (4 and 6, 15 and 46). Blue and red dots represent landmarks (6 in head capsule, 10 in postmentum) and semi-landmarks (48 in head capsule, 20 in postmentum), respectively. The distance between the semi-landmarks is equivalent to the increments of the curve length. Landmark determination in the postmentum follows the linear measurement guide. Roman numerals represent linear measurements.

For example, the head width (HW) and head length to the base mandible (HLBM) characteristics will not be analyzed together with head index characteristics that consisted of the same constituents (HLBM/HW). This was done to avoid high collinearity in the 
exploratory analysis. All the data subjected to multivariate analysis were log 10 transformed before being standardized to minimize skewness and non-normal distribution in some of the data due to allometry effect $[59,60]$.

\subsection{Geometric Morphometric Analysis}

The differences between the HC shapes of C. curvignathus and C. gestroi were subtle when judged by visual assessment (Figure 2), while the HC shape of $C$. gestroi specimens from Batam, Cipinang, and Gunung Sindur visually showed intriguing discrepancies to be further analyzed. It was obvious that the postmentum (hereinafter abbreviated to PS) shape varied depending on each species. Both HC and PS shape were further anatomized landmark-based approach. The PS waist images were taken from the ventral view, while HC images were taken from the dorsal view. The image collection was conducted by setting the specimens on a petri dish with cotton or Styrofoam soaked in $70 \%$ ethanol as a base. Two sets of images were collected using the digital microscope. All of the designated images were chosen and processed using image-processing software (tpsUtil version 1.78) [61]. A total of 210 soldiers were used to collect HC landmarks, 215 soldiers were used to collect PS ventral view landmarks, and 137 soldiers were used to collect PS lateral view landmarks.

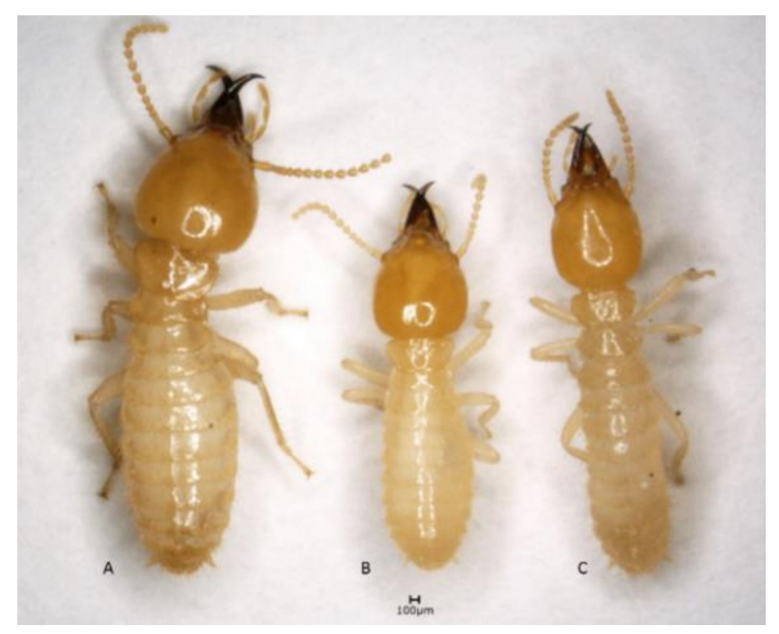

Figure 2. The two species, C. curvignathus (A) and C. gestroi (B,C) look different at first glance. Regardless of the body size, the head capsule (HC) shape of " $\mathrm{B}$ " looked as broad as " $\mathrm{A}$ " rather than that of " $\mathrm{C}$ ". Characteristics of HC shape alone would be unwieldy in the field practice.

Since there was no reference for determining landmarks in the termite HC and PS, landmarks and semi-landmarks were defined to represent the shape of the object and were determined from structures that were easily observed and repeatable. Landmarks are homolog coordinates that indicate a shape or biological form, while semi-landmarks are arbitrary coordinates along a curvature between landmarks [42,62,63]. In the PS, the eight landmarks chosen covered the anterior and posterior margins as well as the widest and narrowest PS width points. In the PS lateral view, two landmarks and 20 semilandmarks were used on the curve. In the HC, six landmarks covering the third anterior part, and 48 semi-landmarks followed the curve of the head starting from the rear of the protruding antennal socket (Figure 1). The semi-landmarks were placed in the direction of the curve [64]. Landmarks and semi-landmarks were established and digitized using data acquisition software (tpsDig2 version 2.31) [65]. Scale factor determination followed the digital microscope scale reference. Full Procrustes-fit was executed to produce shape variables. The method of alignment by principal axis (the default method) was used in the analysis. The wireframe was created by connecting all the landmark centroids available after the superimposition process. The superimposition and collection of shape variables 
were performed using a software program for geometric morphometric analysis (MorphoJ version 1.07a) [44].

\subsection{Statistical Analysis}

Two sets of functional groups were created, i.e., one set for the group of all species and another one for the group of $C$. gestroi, based on the area of collection. The first set of functional groups was defined by three species, namely C. curvignathus, C. gestroi, and C. sepangensis. In a linear morphometric analysis, all C. kalshoveni were considered to be ungrouped cases due to the small number of samples collected in this study. The second set of functional groups consisted of C. gestroi specimens collected at each of seven locations. The functional groups were used in the analysis of linear and geometric morphometrics.

Principal component analysis (PCA) and discriminant functional analysis (DFA) of linear morphometric data and geometric morphometric data were conducted using the statistical packages IBM SPSS Statistics 27 (IBM Corp, Armonk, New York, NY, USA) and the MorphoJ program (version 1.07) [44], respectively. From 34 linear morphometric variables, 24 non-overlapped variables were utilized in PCA to find sets of further correlated characteristics (Table S2). A total of 54 landmarks in two dimensions were used as inputs in shape exploratory analysis.

The DFA was conducted to further polarize the three functional groups of all species and the seven functional locality-based groups of C. gestroi using the head morphology variation in specimens collected from seven locations (West Java province: 10 specimens from Cipinang, 10 from Gunung Sindur, 10 from Parung Panjang, 20 from Cibinong, and 10 from Karadenan; the Special Capital Region of Jakarta: 10 specimens from Pondok Kelapa; and Batam Island: 14 specimens). Collinearity diagnostic analysis was conducted to investigate the multicollinearity effect based on the PCA results. As many as 11 nonmulticollinear characteristics $(\mu \mathrm{m})$ were used in the initial canonical structure matrix to establish purposeful variables for further analysis of all of the species, while in the group of C. gestroi, 16 non-multicollinear characteristics were utilized in a stepwise fashion to independently select variables that would give the most contribution to the separation of the group [66,67]. In the stepwise DFA, Wilk's lambda F value was used (default settings: 3.87 as the entry value; 2.71 as the removal value). Cross-validation was conducted for the results from both the grouping of all species and the $C$. gestroi grouping.

Statistical analysis of the centroid size and procrustes coordinates in geometric morphometric data was conducted in the MorphoJ program (version 1.07a) [44]. PCA was used to observe the shape variation in the procrustes coordinates. Canonical variate analysis (CVA) and DFA were applied to find the shape characteristics that best discriminate the data based on each functional group, respectively. The significance of the mahalanobis and procrustes distance between pairs of groups was assessed in 10,000 permutation runs. The total shape change was shown in transformation grids. To test the influence of size on the shape, regression analysis of each functional group was conducted in 10,000 permutation runs with procrustes distance and centroid size as data matrices $[47,68]$. Pool regression within group (C. curvignathus, C. gestroi, C. sepangensis, and C. kalshoveni) was applied to the PS shape's procrustes distance. The differences in PS and HC shape within all species and within the group of $C$. gestroi were evaluated. The regression residuals value of procrustes coordinates was further utilized to perform grouping assessment. The level of significance in all statistical analysis in this study was $p<0.05$.

\subsection{Phylogenetic Analysis}

The DNA extraction was carried out using one individual soldier of each species and one individual from each of the seven locations from which C. gestroi were collected (West Java province: Cipinang, Gunung Sindur, Cibinong, Karadenan, and Parungpanjang; the Special Capital Region of Jakarta: Pondok Kelapa; and Batam Island). The whole termite body was used and ground in a $1.5-\mathrm{mL}$ vial to extract the total genomic DNA by following the protocol of the Gentra Puregene Tissue Kit (Qiagen GmbH, Hilden, 
Germany). Two pairs of mitochondrial primers were used for targeting the $12 \mathrm{~S}$ and $16 \mathrm{~S}$ genes. Amplification of the $12 \mathrm{~S}$ gene was performed by $12 \mathrm{SF}$ (5'-TACTATGTTACGACTTAT$\left.3^{\prime}\right)$ and 12SR (5'-AAACTAGGATTAGATACCC-3') [40,69], while 16SF1 (modified) (5'GATWACGCTGTTATCCCTAAG-3') and 16SR-N/A-03 (designed in the present study) (5'-GTTAAGATTAAGGGGGACTAG-3') were used to amplify the $16 \mathrm{~S}$ gene.

The polymerase chain reaction cycles were as follows: precycle denaturation $\left(94^{\circ} \mathrm{C}-3 \mathrm{~min}\right)$; 40 cycles of denaturation $\left(94^{\circ} \mathrm{C}-30 \mathrm{~s}\right)$, annealing $\left(45^{\circ} \mathrm{C}\right.$ for $12 \mathrm{~s}$ and $50{ }^{\circ} \mathrm{C}$ for $\left.16 \mathrm{~s}-45 \mathrm{~s}\right)$, and extension $\left(72{ }^{\circ} \mathrm{C}-1 \mathrm{~min}\right)$; post-cycle extension $\left(72{ }^{\circ} \mathrm{C}-7 \mathrm{~min}\right)$. The amplification results were purified according to the Fastgene purification kit protocol and sequenced by DNA Sequencing Core, Kyoto University, Kyoto, Japan, and Eurofins DNA Sequence, Tokyo, Japan.

The sequence results were manually edited and combined by using a biological sequence alignment editor (BioEdit version 7.0.5.3) [70] before the analysis was performed. The multiple alignments of several consensus sequences were performed using a multiple alignment program (ClustalX 2.1) [71]. Odontetermes sp. was used as an outgroup in the analysis. The other sequences of Coptotermes spp. included in the study were recruited from GenBank (www.ncbi.nlm.nih.gov (accessed on 28 May 2020)) (Table 1). The genetic distance was analyzed according to the Kimura two-parameter model of sequence evolution in Mega 5.2 [72,73]. The substitution model was set using a nucleotide substitution model selection script (Kakusan 3.0) [74]. Phylogeny analysis was conducted by the Bayesian inference method using MrBayes 3.2.7a [75] and by the maximum likelihood method using Mega 5.2 [76]. A maximum likelihood test was done with 10,000 bootstrap replications, and the GTR+G substitution model was used. Bayesian N-generation was $10 \times 10^{6}$ with $3 \times 10^{5}$ burn-in, and the substitution model was GTR_G (the number of rate categories of gamma distribution was set to eight, and the state frequencies were set to [1]) for each partitioned gene. The tree was edited in a graphical viewer (Figure Tree 1.4.3). The confidence level was labeled at the nodes. Bootstrap levels equal to $70 \%$ or higher were considered to show the true clade [77]. When using MrBayes, a 95\% probability or higher was considered significant [78-80].

Table 1. Specimens list from the study and several sequences from other studies that were included in the genetic analysis. * CMG: Complete mitochondrial genome.

\begin{tabular}{llccc}
\hline \multirow{2}{*}{ Sample Code } & \multicolumn{2}{c}{ Species } & Collecting Site & \multicolumn{2}{c}{ GenBank Accession Number } \\
\cline { 3 - 5 } & \multicolumn{2}{c}{ Samples from This Study } & 16S \\
\hline CPCG001INA & C. gestroi & Cipinang, Indonesia & MW765243 & MW765223 \\
GSCG001INA & C. gestroi & Gunung Sindur, Indonesia & MW765244 & MW765224 \\
KRCG001INA & C. gestroi & Karadenan, Indonesia & MW765246 & MW765226 \\
PPCG001INA & C. gestroi & Parung Panjang, Indonesia & MW765247 & MW765227 \\
CICG001INA & C. gestroi & Cibinong, Indonesia & MW765248 & MW765228 \\
PKCG002INA & C. gestroi & Pondok Kelapa, Indonesia & MW765250 & MW765230 \\
BTCG001INA & C. gestroi & Batam, Indonesia Col. 1 & MW765245 & MW765225 \\
BTCG002INA & C. gestroi & Batam, Indonesia Col. 2 & MW765249 & MW765229 \\
BTCS001INA & C. sepangensis & Batam, Indonesia & MW765251 & MW765231 \\
SICS001INA & C. sepangensis & Alafan Simeulue, Indonesia & MW765252 & MW765232 \\
PPCK001INA & C. kalshoveni & Parung Panjang, Indonesia & MW765254 & MW765234 \\
PPCC001INA & C. curvignathus & Parung Panjang, Indonesia & MW765255 & MW765235 \\
SICC001INA & C. curvignathus & East Simeulue, Indonesia & MW765256 & MW765236 \\
KBCC001INA & C. curvignathus & Karimunbesar, Indonesia & MW765257 & MW765237 \\
ASCC003INA & C. elisae & Asmat, Papua, Indonesia & MW765260 & MW765240 \\
WYCF001JP & C. formosanus & Wakayama, Japan & MW765261 & MW765241 \\
CIOJ001INA & Odontotermes sp. & Cibinong, Indonesia & MW765262 & MW765242 \\
\hline
\end{tabular}


Table 1. Cont.

\begin{tabular}{cccc}
\hline \multirow{2}{*}{ Sample Code } & Collecting Site & GenBank Accession Number \\
\cline { 3 - 3 } & \multicolumn{2}{c}{ Samples from other studies } & 12S \\
\hline C. gestroi & Singapore & CMG * \\
C. heimi & Pakistan & KU925205 \\
C. heimi & Pakistan & KU925206 \\
C. sepangensis & Brunei & KU925208 \\
C. kalshoveni & Singapore & KU925209 \\
C. kalshoveni & Thailand & KU925210 \\
C. formosanus & Okinawa Island, Okinawa & AB626145 \\
C. formosanus & Iriomote Island, Okinawa & AB626147 \\
H. malabaricus & India & KU925227 \\
H. validus & Australia & KU925235 \\
P. canalifrons & Réunion Island, France & KP026256 \\
R. leptomandibularis & Zhejiang, China & MK41931 \\
\hline
\end{tabular}

\section{Results}

\subsection{Soldier Morphology Characteristics of Coptotermes (Wasmann)}

In this analysis, 44 qualitative characteristics and 34 quantitative data were collected (Tables S1 and S3). The morphology of each species is illustrated in Figure 3. Coptotermes curvignathus was the largest species observed in this study. It generally had a subangularshaped and posteriorly bulged HC with a considerable number of setae on the HC (31-56) and pronotum (61-113 setae). Generally, one pair of setae was observed around the fontanelle. However, the setae varied in number from 1-4. At the tip of the labrum, there was one pair of long terminal setae and one pair of medium-length para-terminal setae $(2+2 \mathrm{M}$ labrum seta formula) (Figure $4 \mathrm{~b})$. The mandibles were strongly incurved. Ventrally, a low waist PS was observed with diverse numbers of setae ranging up to 18 at the anterior edge.
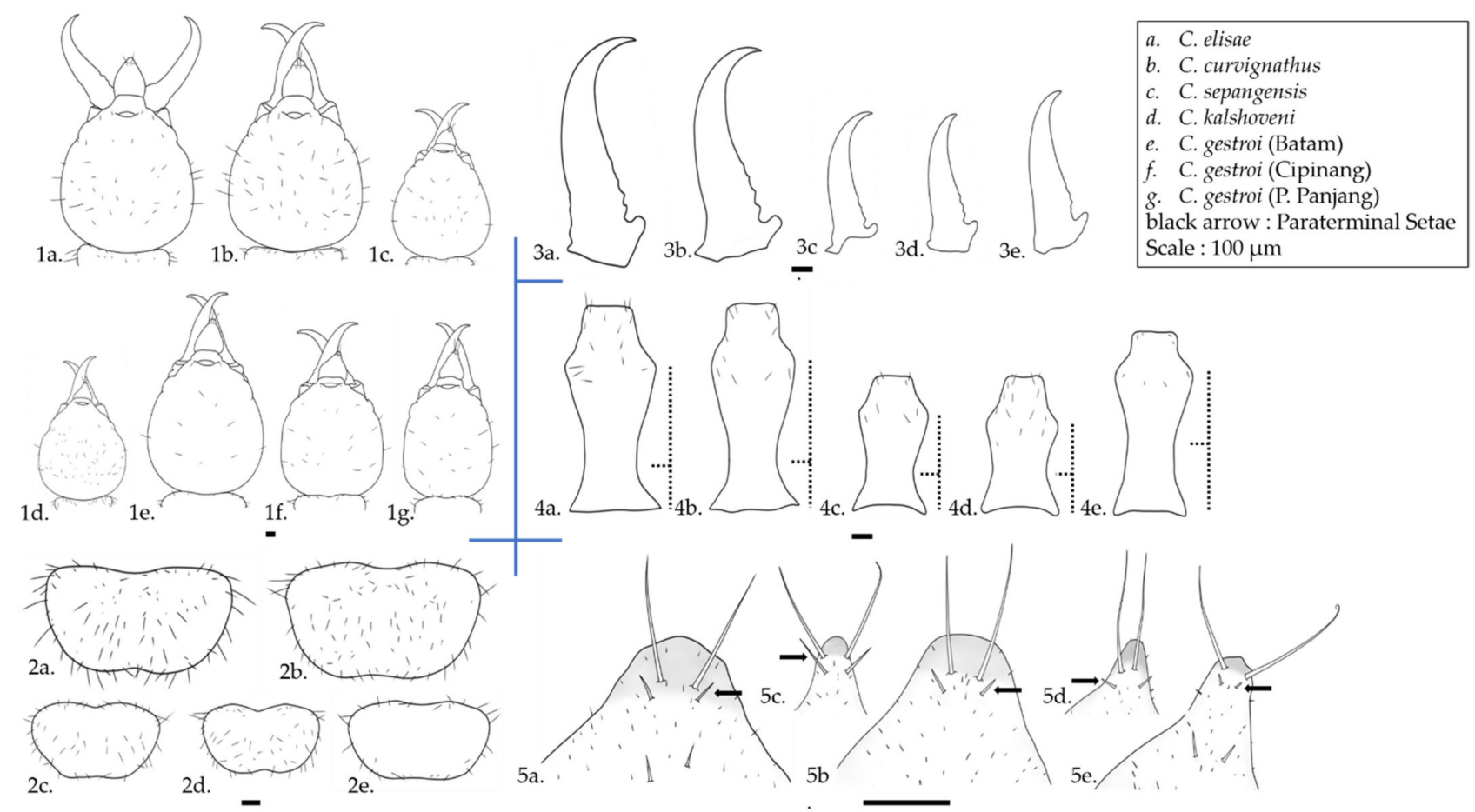

Figure 3. Comparison of Coptotermes spp. ((1). Head capsule, (2). Pronotum, (3). Left mandible curvature, (4). Postmentum, (5). Labrum paraterminal setae). Tracing was conducted in Autodesk Sketchbook version 8.7.1. Scale in $100 \mu \mathrm{m}$. 


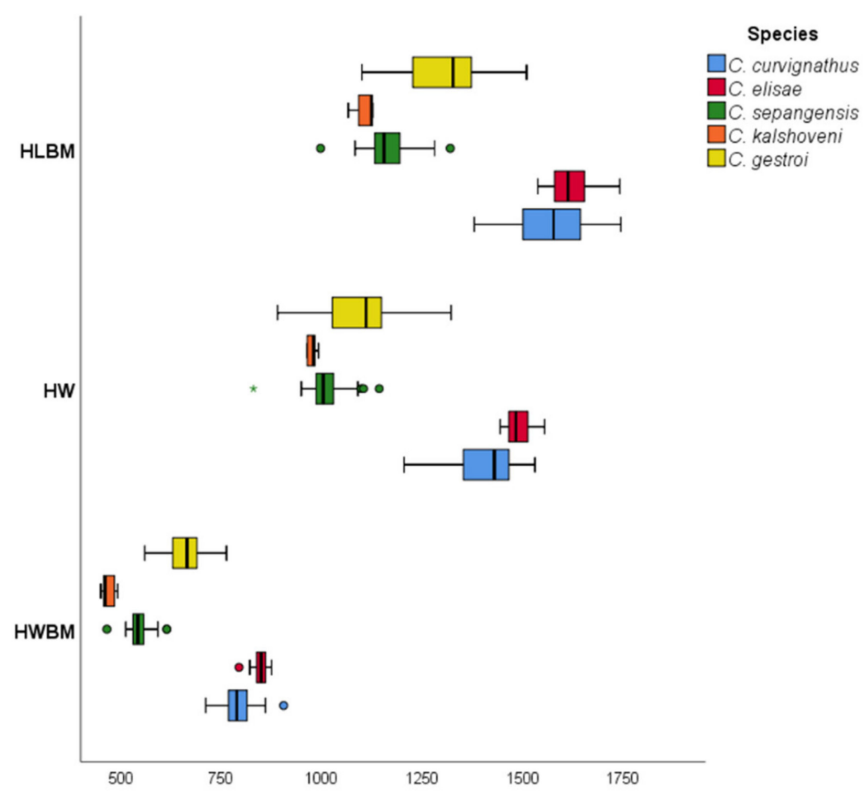

(a).
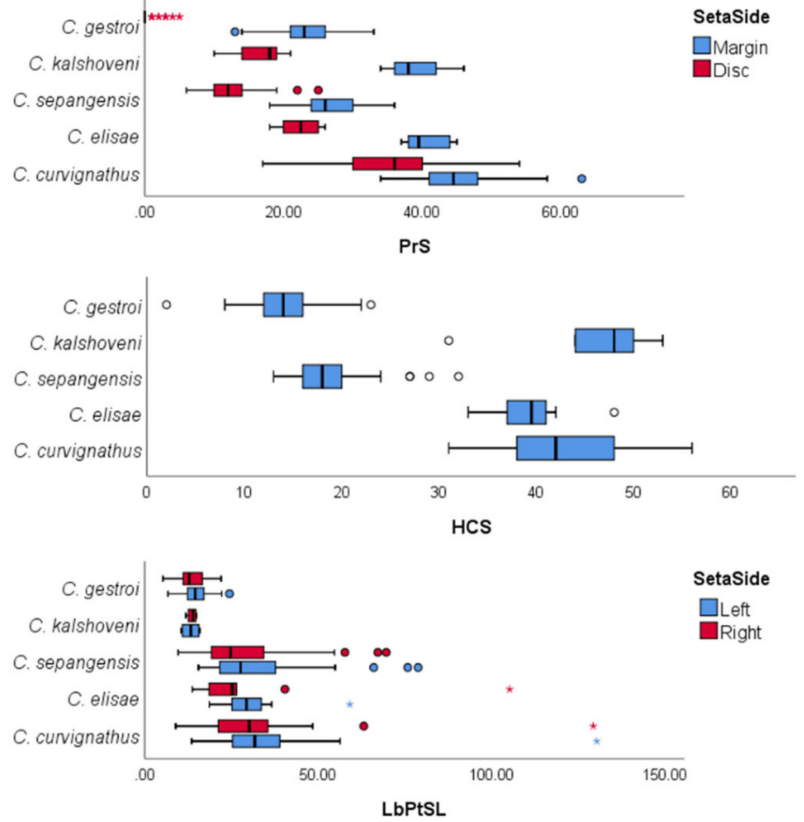

(b).

Figure 4. Multicollinearity showed shifting in a linear fashion of one variable in accordance with the others: (a) Multicollinearity of some variables that are related to the head capsule in clade X of the principal component analysis (PCA), namely the head length to base mandible (HLBM), head width (HW), and head width on the base mandible (HWBM); (b) Fewer collinear variables in clade Y of the PCA, namely the pronotum setae (PrS) and head capsule setae (HCS) including the labrum paraterminal setae length (LbPtSL) of the group of all species. The species (A) and setae positioning (B) are represented in different colors.

Although the number of $C$. elisae samples was very limited $(n=10)$, the body measurements of $C$. elisae overlapped with those of $C$. curvignathus, the sample number of which was much higher in this study. However, the shape of the head was slightly distinguished from that of $C$. curvignathus. We found that it was difficult to distinguish C. elisae from C. curvignathus by solely looking into its soldier morphology without conducting a genetic analysis.

The characteristics of $C$. gestroi were the most varied scale data we observed in this study. Three different HC shapes were observed: (1) Several specimens had broadly oval head-shape, regardless of their size- the head looked similar to the head of C. curvignathus from the dorsal view at first glance; (2) few specimens had subangular head-shape (Figure 2); while (3) majority specimens had the usual egg-shape. The fontanelle was generally decorated by two setae. A variation occurred in which a few individuals in some studied populations had 3-4 setae around the fontanelle. The labrum at the terminal site had one pair of setae and one pair of short para-terminal setae (2+2S labrum seta formula) (Figure $4 \mathrm{~b}$ ). In some specimens, the existence of para-terminal setae was either not obvious or did not exist. The mandibles were slightly incurved, rather straight. The pronotum was flat with setae mostly found at the edge of the pronotum. Few or no setae were observed on the disc part of the pronotum (0-5 setae). Ventrally, the middle waist PS was observed across the samples.

The HC shape of $C$. sepangensis was generally narrow at the anterior part and rounded at the posterior part. A moderate number of setae decorated the HC (13-32 setae). Generally, there were two setae at the fontanelle. A few individuals in the study showed three setae around the fontanelle and it showed $2+2 \mathrm{M}$ labrum seta formula (Figure $4 \mathrm{~b}$ ). The mandibles were quite incurved with curvature starting at the early part of the mandible. The level of curvature varied among specimens. The lateral view showed that the PS bulged ventrally. From the ventral view, a low-waist PS was observed. 
The HC shape of $C$. kalshoveni was generally broad at the medial part with a sudden narrowing at the anterior part just behind the mandible. A massive number of setae was observed on the HC (31-53 setae). Two pairs of setae were situated around the fontanelle. It showed $2+2 \mathrm{~S}$ labrum seta formula (Figure $4 \mathrm{~b}$ ). The mandibles were less incurved, rather straight, with the curvature starting at the final third of the distal part. Laterally, the PS bulged ventrally. From the ventral view, a low-waist PS with a high number of setae (11-13 setae) at the anterior part was observed. In the group of Coptotermes spp. collected in this study, C. kalshoveni was the only species with a waist width wider than the anterior margin width. The pronotum was flat and had a high number of setae scattered on the pronotum disc and marginal side (46-64 setae).

\subsection{Linear Morphometrics}

High pair-wise correlations were observed within 24 of the analyzed data (Figure 4). As many as 14 characteristics had a pair-wise correlation coefficient of more than 0.90 . (Table S1). Diagnostics were conducted to confirm the collinearity of the characteristics by regression linear analysis of highly correlated variables. Since we wanted to use the HW characteristic as one of our predictors, the collinearity diagnostic was conducted with respect to this characteristic. The characteristics that had severe collinearity toward HW were not used in the DFA (collinearity tolerance $<0.1$; variance inflation factor (VIF) $>10$ ) (Tables S4 and S5). As a result, only PsMxW and HW were used in further DFA together with other characteristics that had correlation coefficients less than 0.90 .

The PCA in the group of all species found two components with sets of supportive characteristics (Figure 5). While most of the HC, trunk, and appendage characteristics loaded Component 1 , the data were sufficiently explained by the seta numbers characteristics loading value in Component 2 (loading > 0.5). Both components covered $82.43 \%$ of the cumulative variance (Table S2). In the group of C. gestroi PCA, the distribution of data was mostly explained by Component 1 , which included all sets of supportive characteristics (loading > 0.5). Component 2 did not sufficiently support the data explanation. Both components covered a cumulative variance of $76.79 \%$ (Figure 5, Table S6).

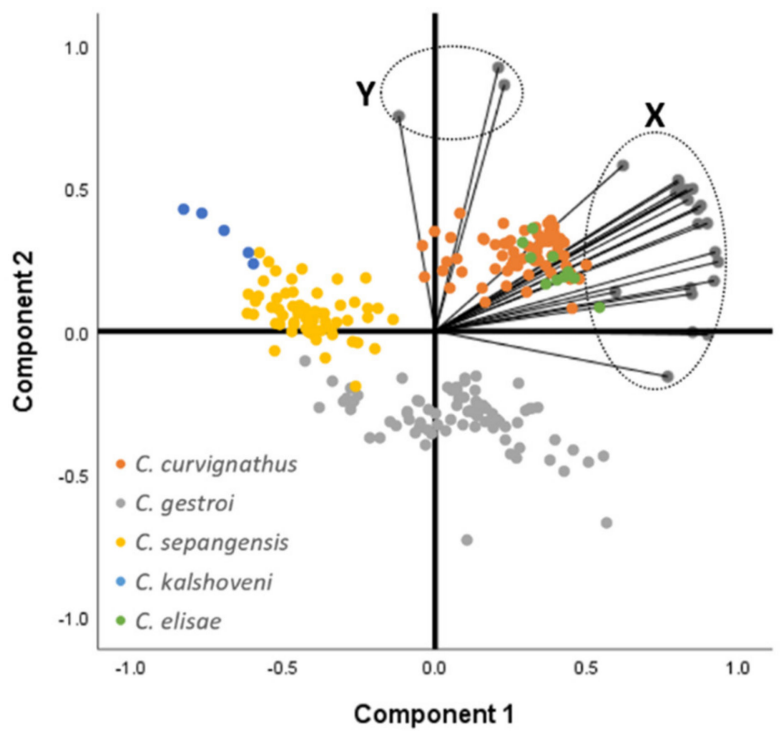

(a).

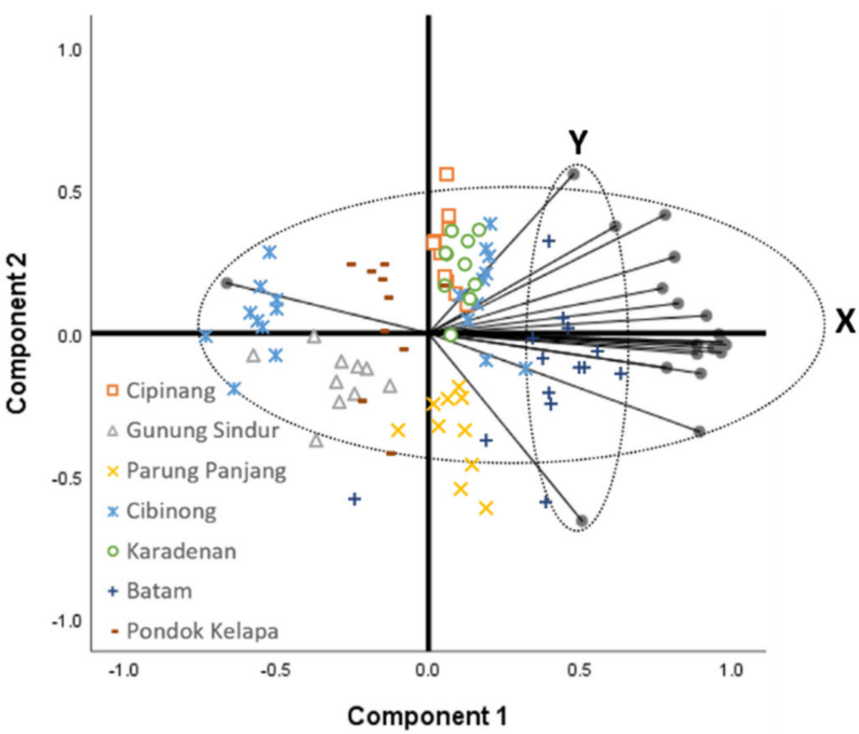

(b).

Figure 5. The principal component analysis biplot graph of: (a) all species ( $\mathrm{n}=228,24$ variables); (b) the group of $C$. gestroi ( $n=84,20$ variables). Species are represented as different shapes. Correlated variables, which headed to the same axis direction, were projected to the collinearity diagnostics. The $X$ variables' clade affected the data distribution along the horizontal axis, and the $\mathrm{Y}$ variables clade affected the data distribution along the vertical axis. 
In the DFA of all species, $99.6 \%$ of grouped cases were correctly classified (crossvalidated). There was a $1.2 \%$ chance that $C$. gestroi was mistakenly classified into $C$. sepangensis (Table S7), while the $C$. kalshoveni group was treated as ungrouped cases. The HC morphometrics, seta numbers, and labium characteristics were explained as important discriminative variables (loading $>0.5$ in Canonical 1 and 2, Table S8). In the discrimination of C. gestroi, 6 of 7 grouped cases overlapped (Table S9) and there was no single characteristic that had unique discriminative ability for the data (Table S10).

\subsection{Geometric Morphometrics}

Geometric morphometric analysis was conducted to determine the magnitudes of PS and HC shape regardless of the size difference. Regression analysis was performed to remove the effects of allometry and size differences within the samples (PS, predicted: $1.5 \%, p$-Value: 0.015 ; HC, predicted: $7.84 \%, p$-Value: $<0.0001)[68,81]$. Shape comparison analyses (CVA and DFA) were then conducted using the residual component from the previous regression.

In the analysis of the HC shape, 52 principal components (PCs) were extracted, and the first and second PCs together were responsible for $74.79 \%$ of the cumulative variance within the samples $(\mathrm{PC} 1=57.24 \%$ and PC2 $=17.55 \%)($ Table S11). It was obvious that PC1 explained the shrunken frons part (landmarks 1-9 and 52-54) and the lateral expansion of the posterior part (landmarks 11-50). A gradual lateral expansion was shown from negative to positive values across the group of all species. PC2 showed the lateral broadening of the middle part of the HC (landmarks 8-18 and 43-54) and the constriction of the most posterior margin (landmarks 22-38) (Figure 6a). Pair-wise cross-validation showed subtle differences in C. sepangensis and C. curvignathus (12.5\% and 9.6\% overlap, respectively), while HC shape differences in C. elisae and C. curvignathus were not obvious. Around $40 \%$ of C. elisae specimens fell into the C. curvignathus group and $14 \%$ of C. curvignathus specimens fell into the C. elisae group (Figure 6b; Table S12). Four trends of HC types were observed in the group of all species (Figure 6c). 


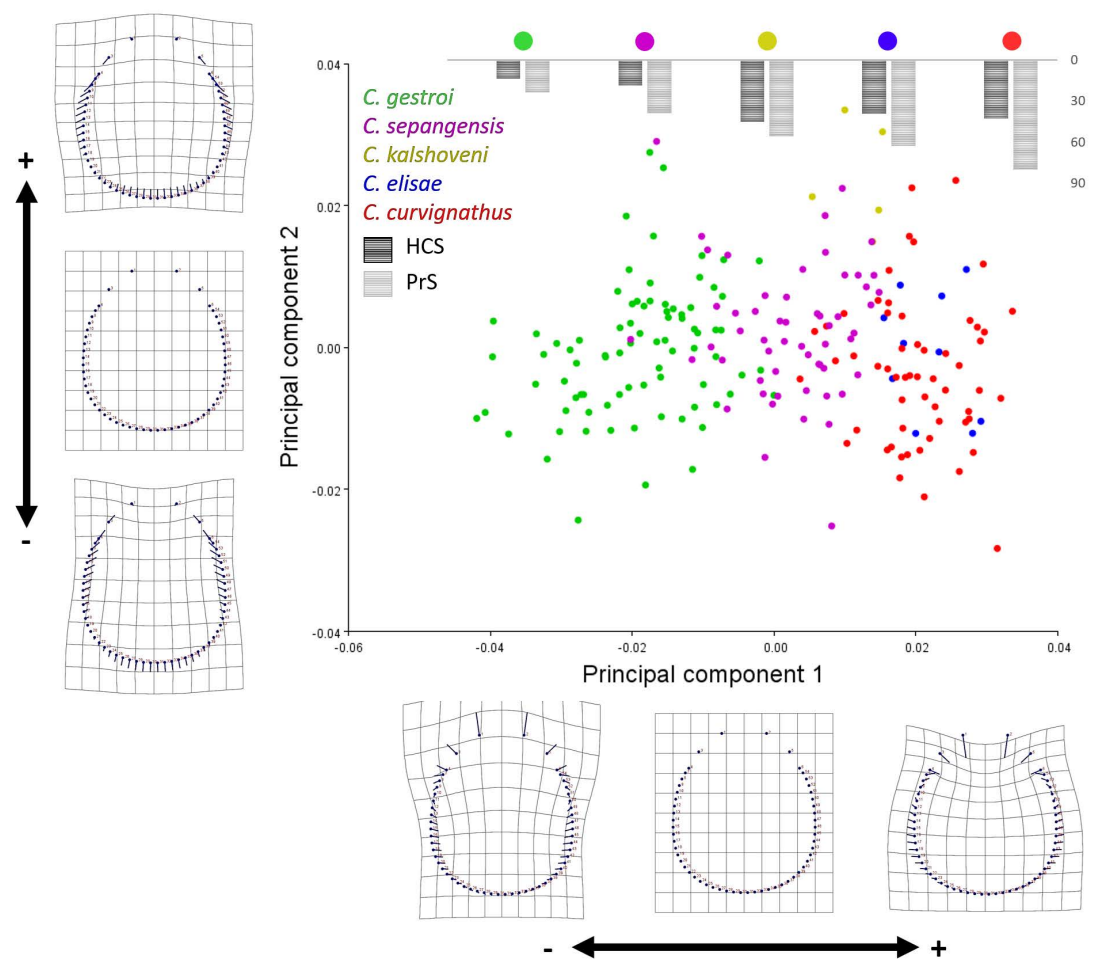

(a).
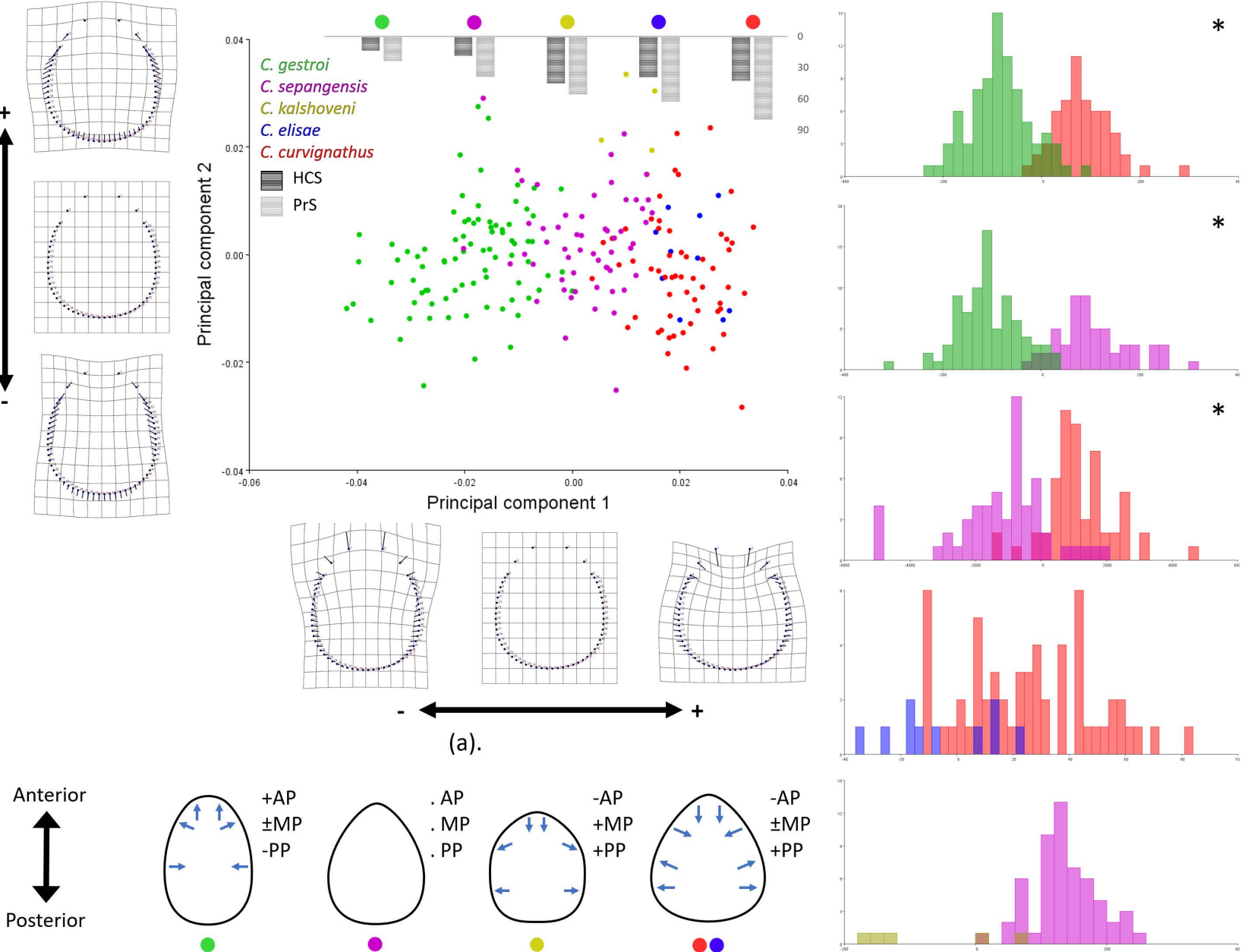

(c).

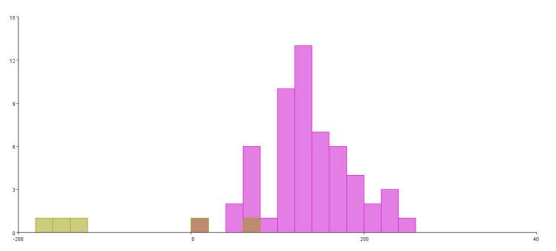

(b).

Figure 6. Head capsule landmarks in the group of all species were subjected to geometric morphometrics analysis using the MorphoJ program: (a) principal component analysis; (b) cross-validation score; (c) illustration of average pattern of head capsule shape. Species were represented in different colors. HCS: Head capsule setae, PrS: Pronotum setae. Significant $p$-Values are represented by asterisks.

In the PS shape analysis, the first and second PCs together were responsible for $85.60 \%$ of the cumulative variance within the samples (PC1: $58.98 \%$ and PC2: $26.62 \%$ ). PC1 explained the change in the PS waist point by moving away from or closer to the posterior margin (landmarks 5-8), while PC2 explained the shape lateral expansion at all landmarks (Figure 7a). CVA and discriminant analysis maximized the group ordination by using species as the criterion. Both the first two canonical variances $(\mathrm{CV})$ were responsible for $93.86 \%$ of the cumulative variance (CV1: $62.67 \%$ and CV2: $31.18 \%$ ) (Table S13). Cross-validation of the pairwise group showed that $12 \%$ of cases were overlapping, as C. curvignathus fell into the C. elisae PS shape group (Figure 7b; Table S14). Three trends of PS shape were observed in the analysis of all species (Figure 7c). 


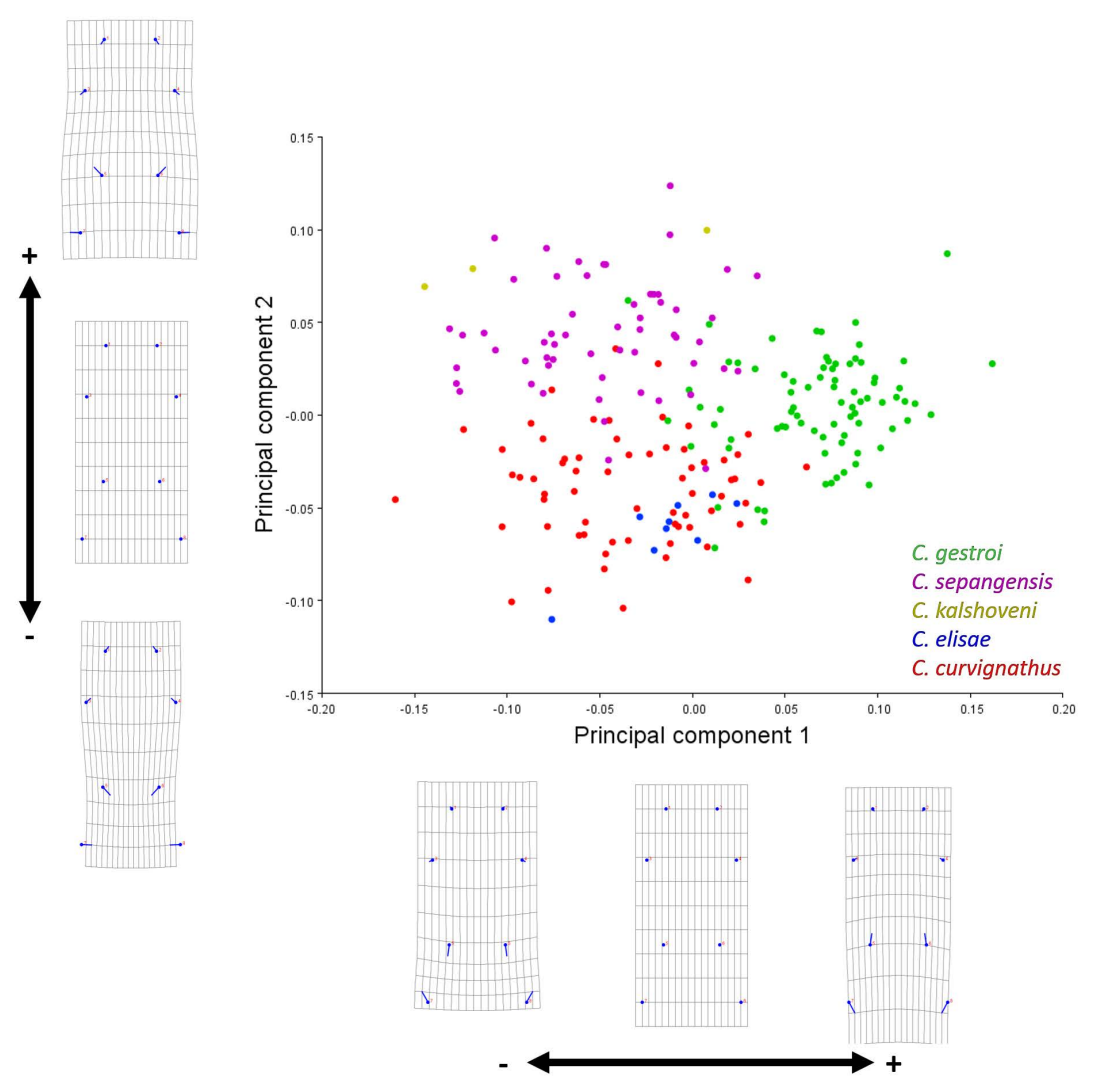

(a).
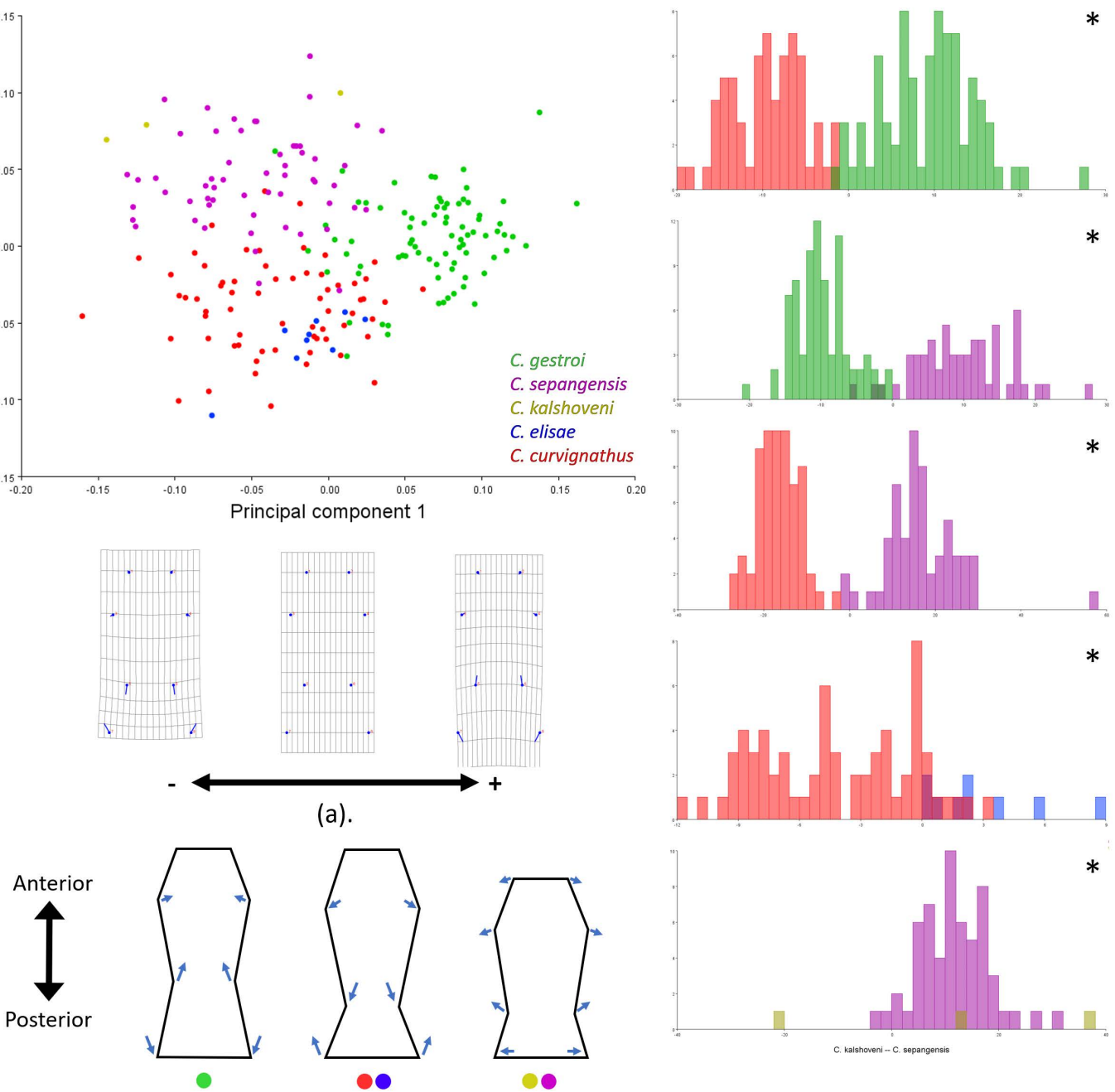

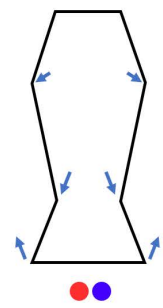

(c).

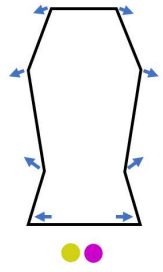

10

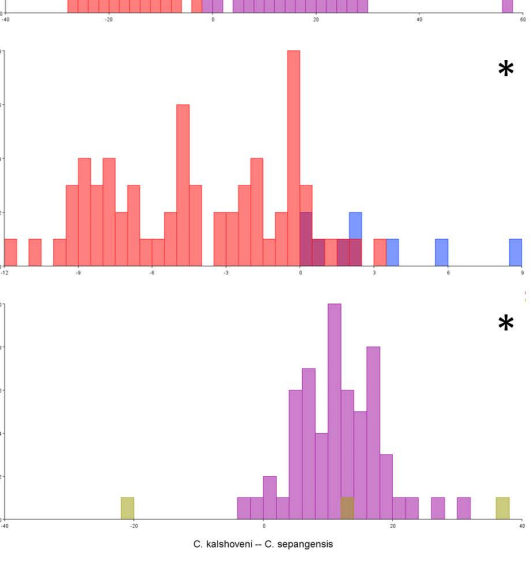

(b).

Figure 7. Postmentum landmarks of the group of all species were subjected to geometric morphometric analysis using the MorphoJ program: (a) Principal component analysis; (b) cross-validation score; (c) illustration of average pattern of the postmentum shape. Species are represented in different colors. Significant $p$-Values are represented by asterisks.

In a lateral view comparison of the PS shape in the group of all species, obvious landmark movement was demonstrated. CVA using PC1 and PC2 (86.17\%) showed the landmarks in the $C$. sepangensis and $C$. kalshoveni groups and explained the ventrally bulged PS (landmarks 7-14), while the PS was relatively flattened in C. curvignathus and C. gestroi (Figure $8 \mathrm{a}, \mathrm{c}$ and Table S15). The cross-validation result showed that $27 \%$ of $C$. curvignathus specimens fell into the $C$. gestroi group, and $12.7 \%$ of $C$. gestroi specimens fell into the C. curvignathus group. As many as $12 \%$ of $C$. sepangensis specimens fell into the $C$. kalshoveni group, and $25 \%$ of $C$. kalshoveni specimens fell into the $C$. sepangensis group. In a similar finding, a considerable number $(21.2 \%)$ of $C$. curvignathus specimens were grouped into the $C$. elisae group (Figure 8b; Table S16). Two shape trends were observed in the analysis of all species. A small sample number of $C$. kalshoveni and C. elisae might be inadequate to be used in the significancy test. Hence, it could affect the validation result against the other species. 

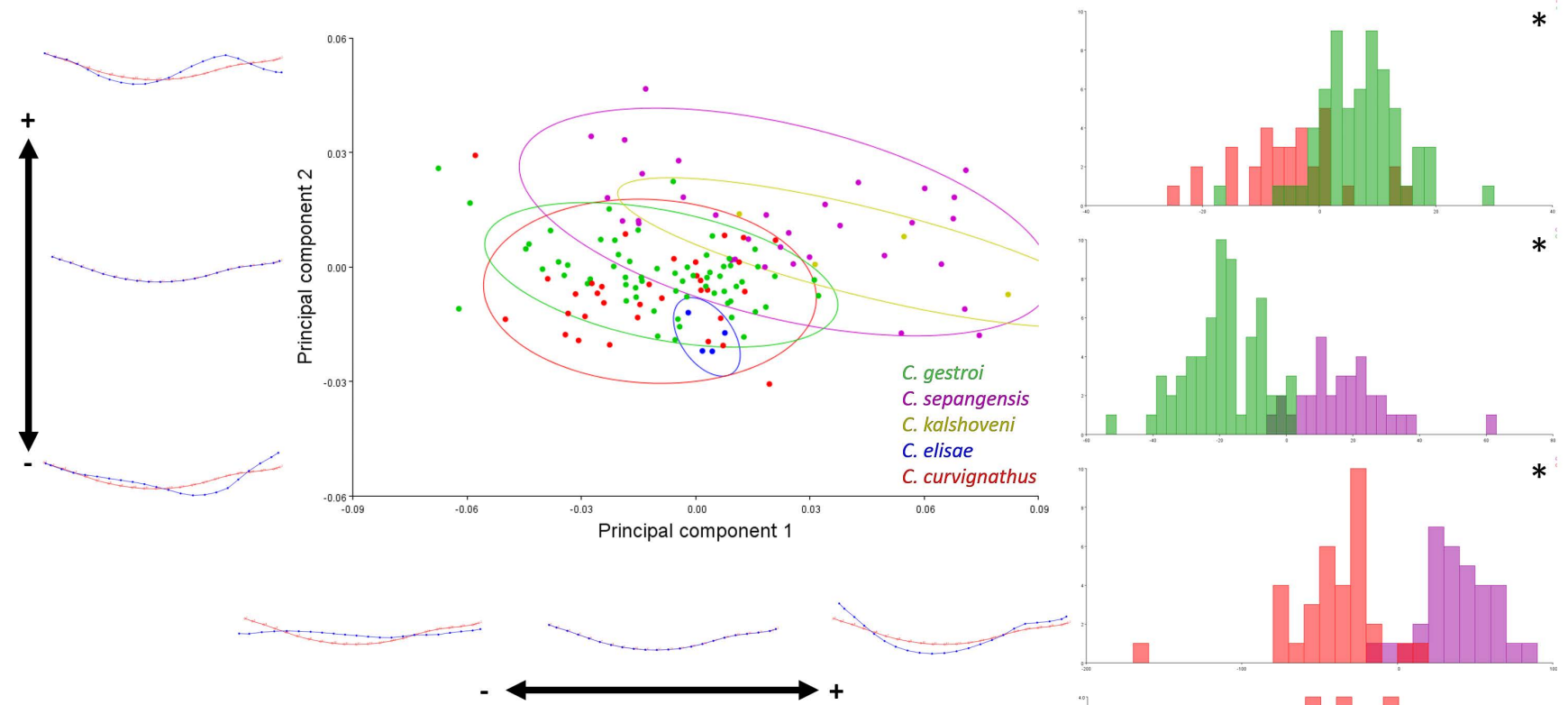

(a).

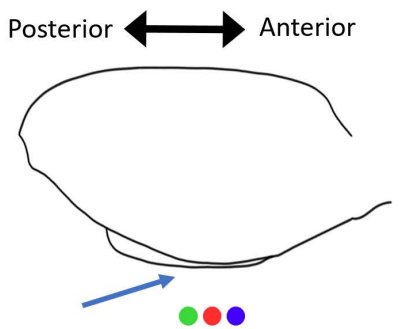

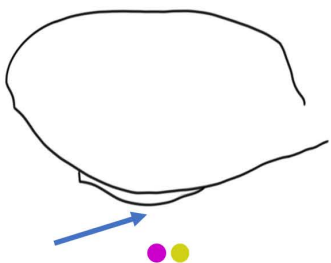

(c).

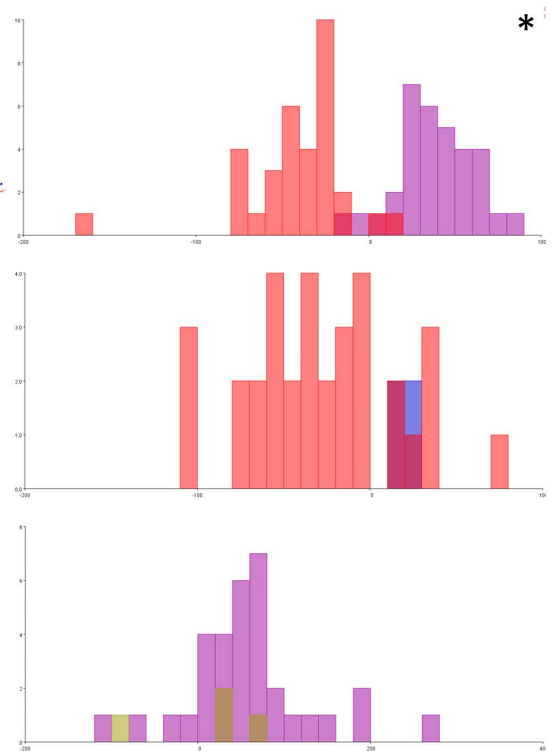

(b).

Figure 8. Postmentum lateral view landmarks of the group of all species were subjected to geometric morphometric analysis using the MorphoJ program: (a) Principal component analysis; (b) cross-validation score; (c) illustration of PS shape lateral view average pattern. Species are represented in different colors. Significant $p$-Values are represented by asterisks.

Interestingly, the results of the analysis of the $\mathrm{HC}$ shape in the group of C. gestroi were consistent with the results for the PS shape analysis. Both PC1 in the two analyses respectively explained the shrinking of the middle and posterior head part $(44.49 \%)$ in the inner direction (landmarks 8-20 and 40-53) and the posterior margin of the inferior part of the PS (50.09\%) to the minimum waist point (landmarks 5-8). PC2 showed lateral expansion in both the head (28.98\%) and PS (30.90\%). The constriction of the anterior parts of the HC and PS shape was explained by each PC3 (12.57\% and $12.90 \%$ respectively) (Figure 9). Some specimens collected at several locations showed extreme shapes, but they overlapped across locations. Three trends in the forms of the HC and PS shape were observed in the group of C. gestroi. 


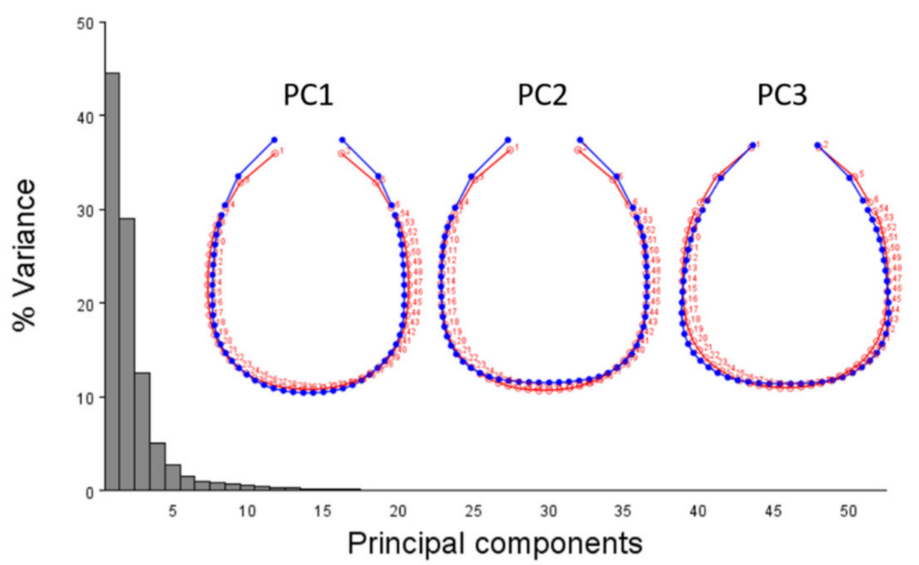

(a).

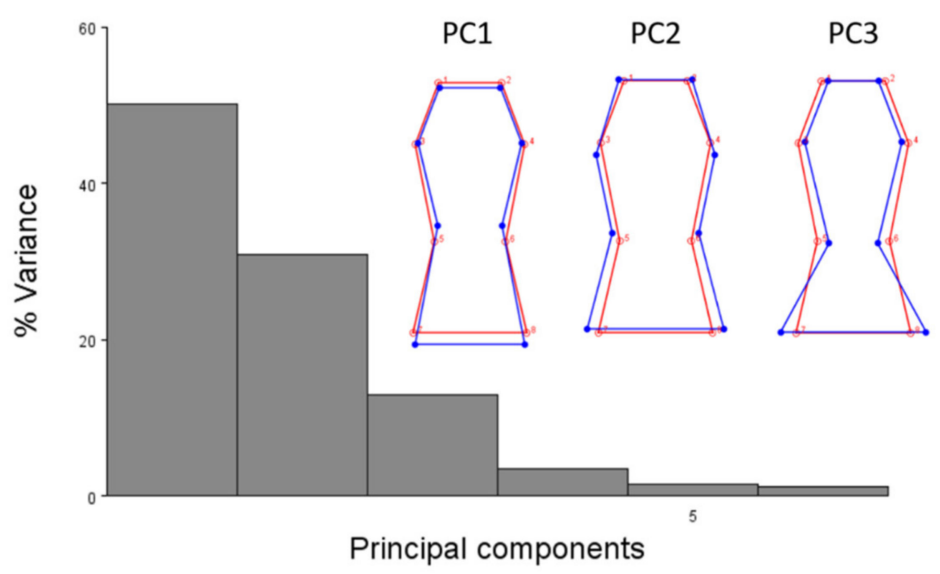

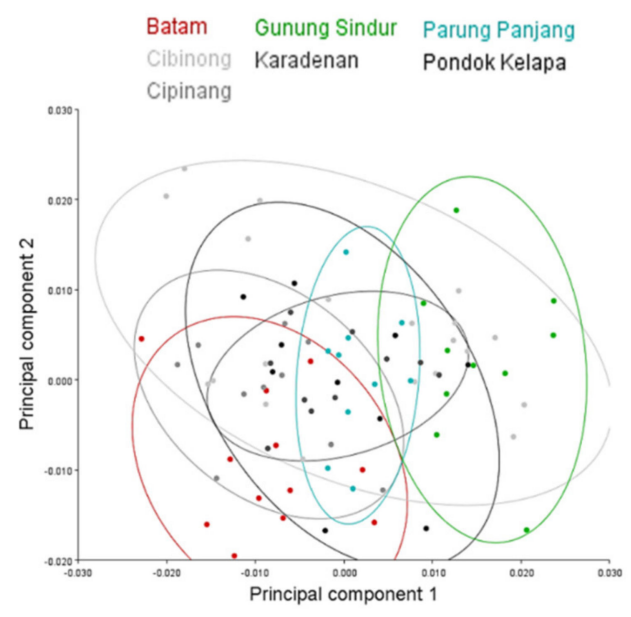

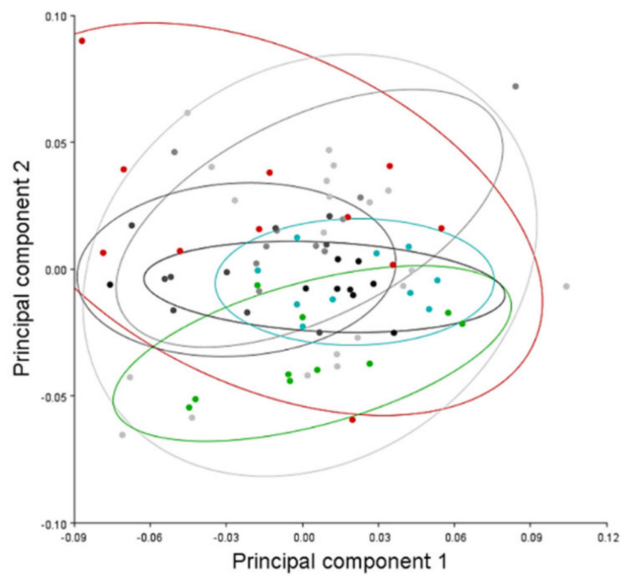

(b).

Figure 9. Head capsule and postmentum landmarks in the group of C. gestroi were subjected to geometric morphometric analysis using the MorphoJ program: (a) Principal component analysis of head capsule shape; (b) principal component analysis of postmentum shape. Functional groups based on different collection sites are represented in different colors.

\subsection{Pairwise Distance of $12 s$ and $16 s$ Genes}

The amplification successfully retrieved $\sim 440 \mathrm{bp}$ of $12 \mathrm{~S}$ sequences and $\sim 680 \mathrm{bp}$ of $16 \mathrm{~s}$ sequences (Tables S17 and S18). Several Coptotermes spp. sequences from GenBank were included. We analyzed eight populations of Coptotermes spp. from this study and Odontotermes sp. as an outgroup. In $16 \mathrm{~S}$ pairwise distance analysis, 682 characteristics were observed. The genetic distance ranged up to $17.3 \%$. The differences between C. gestroi sequences, including $C$. heimi as its synonym, ranged from $0-1.4 \%$. The differences between different species among Coptotermes spp. ranged from $0.5-5.2 \%$. Additionally, in $12 \mathrm{~S}$ pairwise distance analysis, 442 characteristics were observed. The genetic distance ranged from $0-15 \%$. About $0-2.0 \%$ genetic differences were calculated among $C$. gestroi populations, including C. heimi populations. Different species among the Coptotermes spp. ranged from $0.2-4.0 \%$. The variability range from C. elisae to C. curvignathus was $0.2-0.5 \%$ in both genes. The ranges in C. gestroi and C. heimi were $1-2 \%$ in $12 \mathrm{~s}$ and $0.7-1.4 \%$ in $16 \mathrm{~s}$. The distances from C. kalshoveni to C. sepangensis were $1.2-1.5 \%$ and $2.2-2.9 \%$ in $12 \mathrm{~s}$ and $16 \mathrm{~s}$, respectively.

\subsection{Phylogenetic Relationship Inferred from Mitochondrial Genes}

The trees for each and combined genes were constructed with Odontotermes sp. as an outgroup from Termitidae. Reticulitermes mandibularis, Prorhinotermes canalifrons, Het- 
erotermes validus, and Heterotermes malabaricus were used as outgroups as members of Rhinotermitidae. Coptotermes heimi, which was suggested to be a junior synonym of C. gestroi [40], was also included in the analysis. The tree topology resulting from combined genes analysis produced seven clades of Coptotermes spp. with strong probability.

Clade I included C. formosanus from Iriomote Island and the Okinawa Islands nested with the sample from Wakayama, Japan [82]. Clade II consisted of C. kalshoveni from Singapore and Thailand together with a sample of C. kalshoveni from Parung Panjang, Indonesia. Clade III consisted of C. sepangensis from Brunei [83] and C. sepangensis from Simeulue Island and Batam Islands, Indonesia. Clade IV included C. curvignathus from Karimunbesar Island, Parung Panjang, and Simeulue Island, Indonesia, and Clade V contained C. elisae from Asmat regency, Indonesia, and New Guinea [83]. Clade VI included C. Heimi from Pakistan [83], and Clade VII contained all C. gestroi populations from this study nested together with C. gestroi from Singapore [83]. The combined genes tree provided by a Bayesian inference was similar to the maximum likelihood tree topology using $12 \mathrm{~S}$ and $16 \mathrm{~S}$ fragments (Figures S1 and S2). The only difference was that C. formosanus was grouped with $H$. validus and was the closest group to the rest of the Coptotermes spp. in the maximum likelihood test of 16S. The tree in this study is similar to those in other studies in which Heterotermes nestled among Coptotermes [48,83,84] (Figure 10).

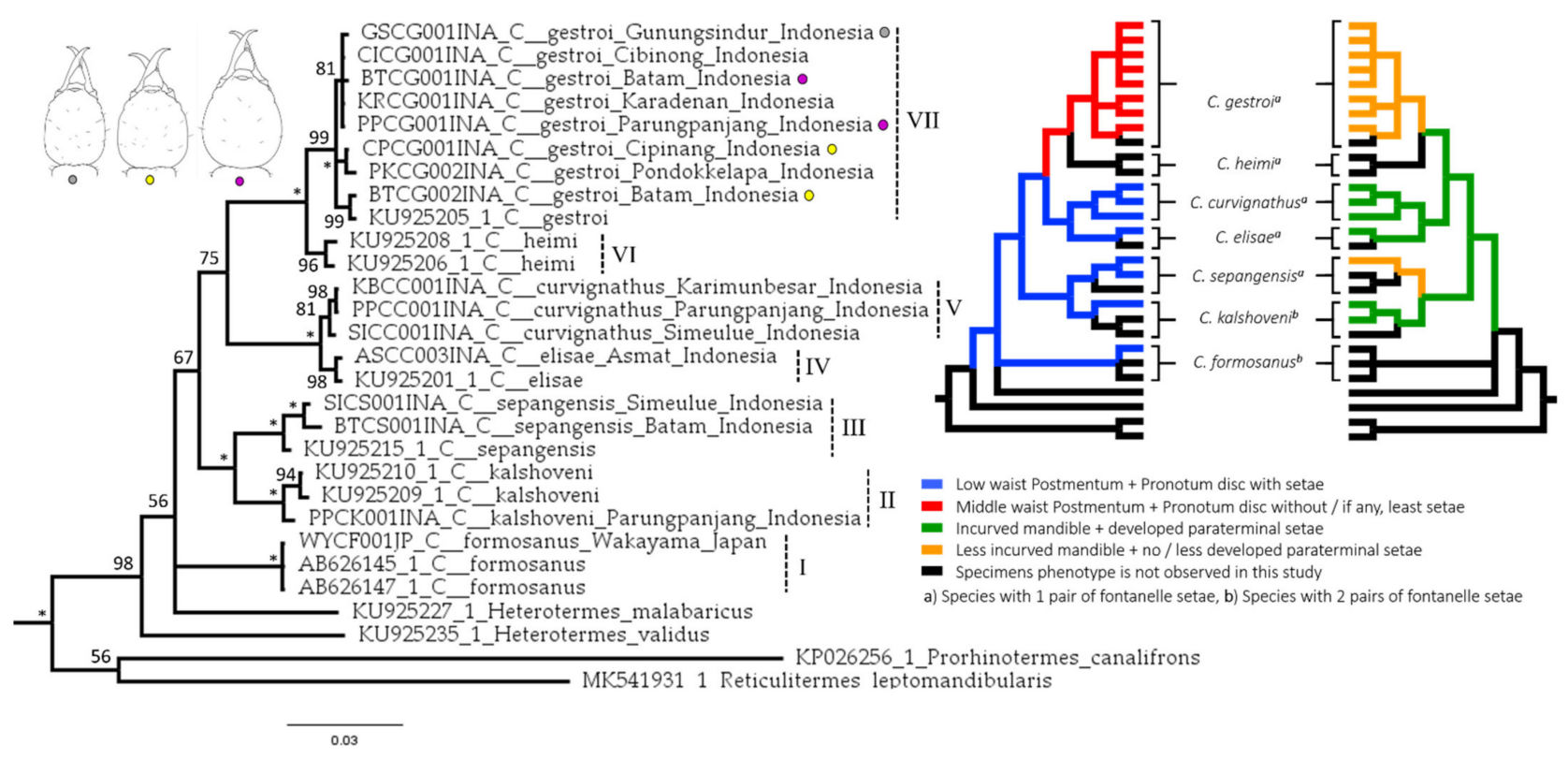

Figure 10. The tree inferred from combined $16 \mathrm{~s}$ and $12 \mathrm{~s}$ rRNA gene fragments ( 1127 bp) using MrBayes 3.2.7. The sequences with sample codes were taken from the NCBI database. A $100 \%$ probability is represented by an asterisk $\left({ }^{*}\right)$ at the node. The Roman numerals represent clades, and the three extreme shape differences in the group of $C$. gestroi are shown in the different gray, purple, and yellow circles in the phylogeny tree. The pair of characteristics is displayed using different colors, while the pairing of fontanelle setae characteristics is shown using the superscripts " $a$ " and " $b$ ".

The tree may also explain how the group of characteristics was formed (Figure 10). Coptotermes gestroi evolved as a monophyletic clade in Coptotermes spp. sharing the characteristics of a middle-waist PS and less-developed setae on the pronotum disc. The other Coptotermes in this study possessed a low-waist PS accompanied by a pronotum with setae on its disc. A less-incurved mandible and less-developed para-terminal setae were independently evolved. Although C. kalshoveni was represented by a small number of specimens, it was obvious that each C. kalshoveni specimen had two pairs of setae around the fontanelle and could be discriminated from other Coptotermes observed in this study. There was, however, a small chance that C. gestroi and C. curvignathus specimens exhibiting two pairs of fontanelle setae were found in nature (Figure 11). 


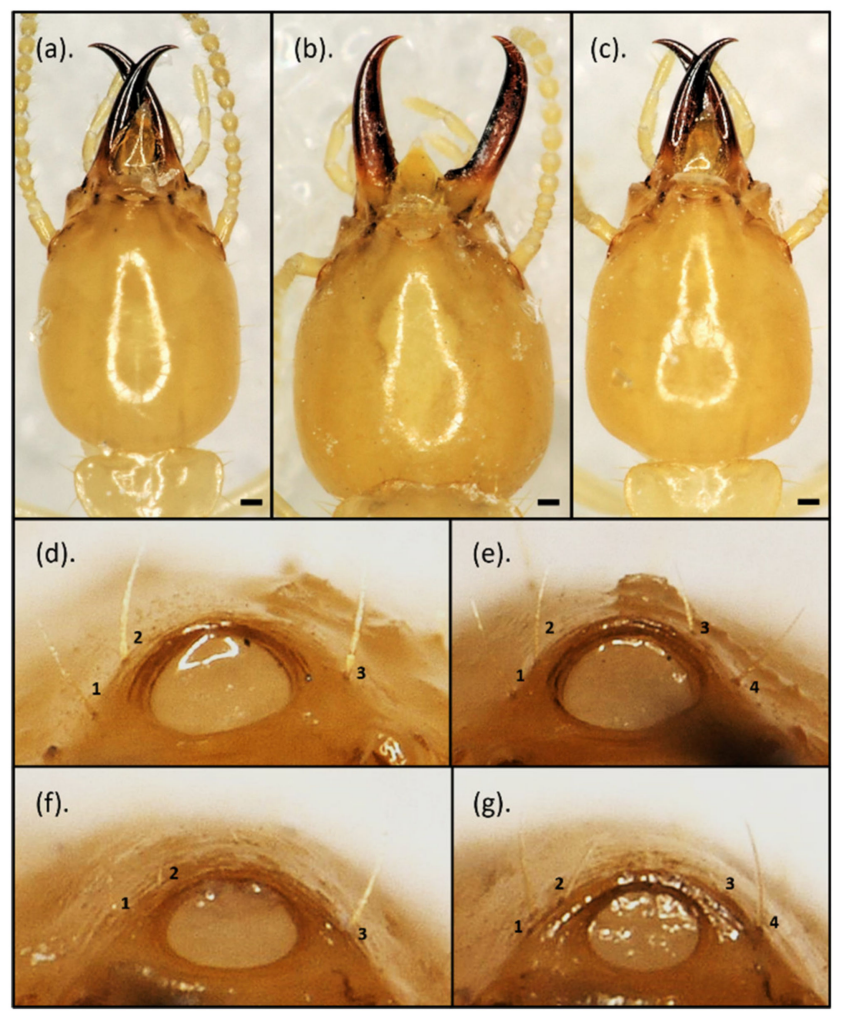

Figure 11. The three extreme head capsule shapes of Coptotermes gestroi were explained by geometric morphometric analysis and by variation in the number of fontanelle setae. $(\mathbf{a}-\mathbf{c})$ : Specimens from (a) Gunung Sindur, (b) Batam Island, and (c) Parung Panjang populations: (d) Coptotermes curvignathus with three fontanelle setae, (e) C. curvignathus with four fontanelle setae, (f) C. gestroi with three fontanelle setae, and (g) C. gestroi with four fontanelle setae. The pictures were taken on the same scale.

\section{Discussion}

\subsection{Important Noticeable Characteristics}

Coptotermes (Wasmann) is an exceptional group of Rhinotermitidae that is decorated by well-developed dome-like frons ending in a large opening fontanelle $[85,86]$. The number of setae around the fontanelle is a very important characteristic that discriminates $C$. formosanus from $C$. gestroi in regions with overlapping swarms, such as Florida (U.S.) [87-89] and Taiwan [90]. C. gestroi has been known to have a pair of setae around the fontanelle, while $C$. formosanus has two pairs of setae $[87,88]$. Although we observed a few variations in C. gestroi (2-4 setae), C. sepangensis (2-3 setae), and C. curvignathus (1-4 setae) (Figure 11), most of the specimens observed had one pair of fontanelle setae. This variation of fontanelle setae was also observed on the soldiers of laboratory cultured incipient colony [91]. Coptotermes kalshoveni exhibited two pairs of fontanelle setae across five observed specimens.

The seta arrangement on the upper face of the labrum varies among Coptotermes spp. [92]. It also has been well-illustrated in several identification references [26,52,53,93]. In this study, variation in lengths of the para-terminal setae discriminated two groups of species, with C. gestroi and C. kalshoveni having one pair that is relatively less-developed compared to those of C. elisae, C. curvignathus, and C. sepangensis (Figure 3). The lessdeveloped para-terminal setae coexisted with a less incurved mandible (Figure 10).

Apart from showing their characteristics' importance, multicollinearity of size characteristics concealed other variables that were also important, such as the PrS and headcapsule setae (HCS). We found PrS was an important characteristic for the species discrimination process in this study. Considering the pronotum pilosity and PS waist in C. formosanus as described by Chen (2020) [94], the absence of setae on the pronotum disc 
together with the middle PS waist characteristic defined a monophyletic group that may discriminate $C$. gestroi from the other species observed in this study (Figures 3 and 10). The characteristics of setae on the abdomen, labrum and pronotum were also used to discriminate the Odontetermes, Heterotermes and Reticulitermes species complex [28-32].

The size characteristics have been used as primary key species identifiers within the Coptotermes genus $[23,24,26,51,53]$. However, as shown in this study, depending solely on the massive HC size as a characteristic of C. curvignathus has led to confusion with that of C. gestroi. The C. gestroi from Batam Island was observed to have the largest HC among C. gestroi in this study. The range of HLBM sizes was close to that of Roonwal and Chhotani's collection from Assam, while the HW was close to that of Kalshoven's collection from Java $[24,95]$. The C. gestroi of this size was observed to overlap with that of C. curvignathus, and the typical overlap measurements have also been observed in other studies $[22,23,27,52,57,96]$. Mandible curvature consequently has been suggested as the diagnostic characteristic with which to discriminate them [22,57].

Furthermore, the PS of Coptotermes spp. has been well-described in detailed drawings showing the waist appearance in the studied species [24,26,53]. Roonwal and Chhotani [26] measured two head height parameters by either including or excluding the PS to indicate its emergence from the HC. This study also observed a difference in the PS shape in the lateral view of $C$. gestroi, C. curvignathus, and C. elisae against $C$. sepangensis and C. kalshoveni. The latter pair demonstrated a ventrally bulged surface compared to the former pair (Figure 7). Our current study suggested that PS shape (Figure 7) in the ventral view is an additional important characteristic for discriminating C. elisae and C. curvignathus from C. gestroi, while PS shape in the lateral view (Figure 8) can be used to discriminate C. elisae, C. curvignathus, and C. gestroi from C. sepangensis and C. kalshoveni. Thapa's C. kalshoveni descriptions and Tho's suggestion to use mandible curvature to distinguish them from C. sepangensis were also clearly feasible $[27,52]$. It was confirmed in the present study that $C$. kalshoveni has a less incurved mandible compared to that of $C$. sepangensis (Figure 3 ).

\subsection{Putative Function-Related Shape and Size Variation of HC and PS}

The geometric morphometric analysis demonstrated the interspecific variation of the HC shape within the group of all species (Figure 6a). In another study, HW of Reticulitermes speratus was demonstrated to be important in the phragmotic defense by showing a smaller coefficient of variation (CV) compared to the other body parts [97]. Among all species observed in this study, only HW of C. curvignathus, C elisae and C. sepangensis showed smaller CV compared to other head-part measurements (Wikantyoso, unpublished data).

The experiment conducted by Li et al. [89] demonstrated C. gestroi to be more attacking and aggressive in interspecific competition compared to C. formosanus. In this study, setae numbers in Coptotermes spp. increased as the posterior HC laterally expanded. Hairlike setae or sensilla with specific cuticular profile may sense vibration or tactical stimulation [98-103]. Hence, species with more setae might evolve to have better ability to sense vibration from their surroundings, such as performing an eavesdropping mechanism to detect the nearest competitor or predator-walking impulse [104,105]. Based on this information, the Coptotermes soldier might evolve so that the species with more setae and laterally expanded HC would be more sensitive to vibro-acoustic cues and have greater advantage of phragmosis in the tunnel defense, while the one with fewer setae and slender $\mathrm{HC}$ would be more impulsive and rush their natural competitor or predator during interception.

The HC shape and mandible are suggested to become an intact set of characteristics in the evolution process [106]. Different levels of mandible curvature independently evolved in Coptotermes and were not correlated with the HC posterior lateral expansion. Lateral expansion of the HC posterior part may be associated with the wider attachment area of the craniomandibular muscle that will amplify bite force [106-108]. We assumed craniomandibular muscle development affects the postmentum elongation and $\mathrm{HC}$ widening during soldier differentiation in Coptotermes. The structure of the mandible closer-muscle in 
Hodotermopsis sjostedti (bn4) seems to have a role in constraining the postmentum waist [20], of which praementum retraction muscles attach $[109,110]$.

\subsection{Impact of Coptotermes Head Shape Perplexity on Indonesia Termite Pest Management}

Termite pest determination strongly depends on the existence of a white wax-like secretion of the large frontal hole, which is usually used to discriminate Coptotermes from other genera. However, the assessment of head-shape characteristics is crucial when it comes to species description [86,94]. Not only is the sclerotized part able to withstand preservation, but $\mathrm{HC}$ of termites were unpalatable to their predator of equal size $[18,111]$.

In Hanoi, Vietnam, termite pests were identified with two types of HC shapes that genetically fall in the same phylogenetic clade of C. gestroi [21]. In the present study, three extreme types of head shapes that constitute more than $90 \%$ of the variance in data samples were nested together. A population from Gunung Sindur showed a shrinking middle-head part that resembled an oval or egg-shaped HC, which is similar to that of C. gestroi from Hanoi (C2 in Hanh et al. [21]). In the other specimens from Parung Panjang and Batam Island, the posterior part of the head was laterally broadened to resemble the shape of a waterdrop. Despite the subjectivity in determining these shapes, head-shape variation is widely considered to be a striking characteristic of the $\mathrm{HC}$ in C. gestroi and C. curvignathus during field assessment [112-116]. Hence, relying solely on HC shape is not sufficient for termite pest determination on the field.

Notably in this study, C. elisae and C. curvignathus had overlapping HC and PS shapes in both the ventral and lateral view analyses. Genetic analysis also explained small genetic distance (below 0.5 in both $12 \mathrm{~s}$ and $16 \mathrm{~s}$ ) between the two species. Furthermore, C. heimi and C. vastator were suggested to be $C$. gestroi synonyms due to their overlapping morphometric characteristics and low genetic variation (below $1.7 \%$ and $0.54 \%$ in $12 \mathrm{~s}$, respectively; $1.4 \%$ and $0.8 \%$ in $16 \mathrm{~s}$, respectively) $[40,49]$. Based on the evidence, we believe that $C$. elisae and C. curvignathus may be synonyms, even though additional thorough evaluations are needed to validate this possibility. This was also proposed by Chouvenc et al. [10], who marked C. curvignathus as nonvalid species and suspected the synonymy of C. elisae and C. curvignathus from their morphology and genetic identity in Bourguignon's unpublished data. The synonym issue of both species could have been affecting the portrait of termite pest distribution in Indonesia.

The distribution of economically important termite pests in the Indonesian archipelago was still globally uncertain [10], while the local mapping of economically important species in several important urban areas in Indonesia was recently conducted [113,116,117]. Likewise, the morphometrics information was still poorly explained. Our data suggested that the shape variation showed a subtle interspecific shape trend in the group of all species, while the HC shape variation in C. gestroi might not be geographically specific. Instability characteristics in C. gestroi soldiers may explain the more environmental stress they get compared to other species in this study [91], such as urban hustle. On the other hand, C. gestroi soldiers evolved morphological traits distinct from others that might partially ease their colony expansion in urban areas, such as less hairlike setae on the pronotum and HC. The small variance value (Wikantyoso, unpublished data) and lopsided distribution of pronotum disc setae characteristics should potentially illustrate the directional selection on the C. gestroi soldier caste (Figure 4). Some insects have had their distribution, behavior, and reproduction affected by anthropogenic activities [118-121]. The coexistence of the broadening of the posterior part of the head with the increasing of the $\mathrm{HC}$ and $\mathrm{PrS}$ or hairlike sensilla might explain the predator-based defense mechanism and the sensitivity to natural predator or human-induced noise, due to which each species could express a distribution preference within urban, suburban, and forest areas in Indonesia.

\section{Conclusions}

This study did not aim to revise the classification of Coptotermes but rather to explore the complexity of the determination of Coptotermes spp. pest species using head-capsule 
(HC) characteristics. Head width (HW), pronotum setae (PrS), and postmentum (PS) characteristics appeared to be important in the discrimination process. Four trends of HC shape were observed with lateral expansion of HC posterior part happening in a gradual manner in C. gestroi, C. sepangensis, and C. curvignathus, successively in that order. Three possible extreme variations were shown to exist in C. gestroi populations in Indonesia, and these variations explained the confusion in C. gestroi species determination. Considering both the ease with which the $\mathrm{HC}$ shape can be observed during field observations and the grouping results in this study, HC shape should be cautiously used to discriminate among Coptotermes spp. In the absence of a species comparison in the field, it is suggested that PrS and PS shape be used rather than linear measurements.

Supplementary Materials: The following are available online at https:/ /www.mdpi.com/article/10 $.3390 /$ insects12050477/s1, Figure S1: Tree inferred from 12S (A) and 16S (B) rRNA gene fragment by using MeBayes 3.2.7. N-generation was $10 \times 10^{6}$ with $3 \times 10^{5}$ burn-in. Substitution model was GTR_G for each gene. Sequences with simple code were taken from NCBI database. A hundred percent probability was represented by asterice ${ }^{*}$ ) at the node, Figure S2: Maximum Likelihood Tree inferred from 12S (A) and 16S (B) rRNA gene fragment by using Mega 5.2. Substitution model was GTR_G for each gene and $1000 \times$ bootstrap replication. Sequences with sample code were taken from NCBI database, Table S1: Measurements of 5 morphospecies observed in this study. *numbers (continued), Table S2: Rotated Component Matrix by Varimax. Two components and seven sets of character were explained. Total \% of Variance covered $82.43 \%$, Table S3: Characteristics comparison of Coptotermes spp, Table S4: Collinearity diagnostics conducted by Linear Regression analysis. Tolerance value $<0.1$ or VIF $>10.00$ explained collinearity. Head width character was treated as dependent variable, Table S5: Collinearity diagnostics conducted by Linear Regression analysis. Tolerance value $<0.1$ or VIF $>10.00$ explained collinearity. Head width character was treated as dependent variable, Table S6: Rotated Component Matrix by Varimax. Two components were extracted. Five sets of character were explained. Total \% of Variance covered were $76.79 \%$, Table S7: The classification results obtained by discriminant function analysis for all of the species. Original and cross-validated classifications were included. Overall, $99.5 \%$ of groupings were solved by 11 variables. Cc: C. curvignathus; Cg: C. gestroi; Cs: C. sepangensis; Ce: C. elisae, Table S8: Standardized canonical discriminant matrix of whole species DFA. Two components were extracted. Five sets of character were explained. Total \% of Variance covered by two components was $100 \%$, Table S9: titleThe classification results obtained by discriminant function analysis for $\mathrm{C}$. gestroi species with head morphology variation. Original and cross-validated classifications were included. Overall, $82.1 \%$ of groupings were step-wisely solved by engaging nine variables. CP: Cipinang; GS: Gunung Sindur; PP: Parung Panjang; CI: Cibinong; KR: Karadenan; BT: Batam; PK: Pondok Kelapa, Table S10: Standardized canonical discriminant matrix by DFA for C. gestroi with head morphology variation. Six components were extracted. Six sets of character were explained. Total \% of Variance covered by the first two components was $64 \%$, Table S11: The amount of data variance covered by the four highest Canonical Variate produced from CVA of the whole species Head Capsule Shape. The number of iterations is 10,000, Table S12: Head Capsule Shape Classification results by DFA for the whole species. In Head Capsule shape analysis, comparisons were done in pairwise way (CC: C. curvignathus; CE: C. elisae; CG: C. gestroi; CK: C. kashoveni; CS: C. sepangensis), Table S13: The amount of data variance covered by three Canonical Variate produced from CVA of the whole species Postmentum Shape. The number of iterations is 10,000, Table S14: Postmentum Shape Classification results by DFA for the whole species. In Postmentum shape analysis, comparisons were done in pairwise way (CC: C. curvignathus; CE: C. elisae; CG: C. gestroi; CK: C. kashoveni; CS: C. sepangensis), Table S15: The amount of data variance covered by the four highest Canonical Variate produced from CVA of the whole species Posmentum Lateral View. The number of iterations is 10,000, Table S16: Postmentum lateral view classification results by DFA for the whole species. In Head Capsule shape analysis, comparisons were done in pairwise way (CC: C. curvignathus; CE: C. elisae; CG: C. gestroi; CK: C. kashoveni; CS: C. sepangensis), Table S17: Pairwise distance matrix (uncorrected p-distances $\%$ ) for all the $12 \mathrm{~S}$ sequence used in this study, Table S18. Pairwise distance matrix (uncorrected p-distances \%) for all the $16 \mathrm{~S}$ sequence used in this study.

Author Contributions: Methodology, B.W., T.Y.; software, B.W., T.Y.; validations, B.W., S.-P.T.; formal analysis, B.W., T.Y.; investigation, B.W., S.-P.T.; termite collection, B.W.; resources, B.W., S.K.H., 
S.Y.; data curations, B.W., S.-P.T., S.K.H., S.Y., T.Y.; writing-original draft preparation, B.W., S.-P.T.; writing-review and editing, B.W.; visualization, B.W., S.-P.T., S.K.H., S.Y., T.Y.; research supervision, S.Y., T.Y. All authors have read and agreed to the published version of the manuscript.

Funding: This research received no external funding.

Institutional Review Board Statement: Not applicable.

Informed Consent Statement: Not applicable.

Data Availability Statement: The data presented in this study are available on request from the corresponding author.

Acknowledgments: The authors would like to thank the Research Center for Biomaterials-Indonesian Institute of Sciences (LIPI). The authors are grateful to Didi Tarmadi, Ikhsan Guswenrivo, Agung Sumarno, Arief Heru Prianto, and Sudarmanto from LIPI for helping with the specimen collection as well as Titik Kartika from LIPI as the project coordinator in the biodiversity exploration of termite and wood-deteriorating fungi in Batam, Kuningan, and Batu Raden Botanical Garden. The authors would like to express their gratitude to the Museum Zoologicum Bogoriense-LIPI, for assisting and providing the specimen loans. The authors also thank the Japan-ASEAN Science Technology Innovation Platform (JASTIP) Program, a collaborative project of Kyoto University and the Indonesian Institute of Sciences (LIPI) under Work-Package (WP) 3: Bioresources and Biodiversity. JASTIP is fully supported by the Strategic International Collaborative Research Program (SICORP) of the Japan Science and Technology Agency (JST), within the framework of the Collaboration Hubs for International Research Program (CHIRP).

Conflicts of Interest: The authors declare no conflict of interest.

\section{References}

1. Abe, T.; Higashi, M. Cellulose Centered Perspective on Terrestrial Community Structure. Oikos 1991, 60, 127-133. [CrossRef]

2. Lee, K.E.; Wood, T.G. Termites and Soils; Academic Press: London, UK, 1971; p. 279.

3. Li, H.-F.; Fujisaki, I.; Su, N.-Y. Predicting Habitat Suitability of Coptotermes gestroi (Isoptera: Rhinotermitidae) with Species Distribution Models. J. Econ. Entomol. 2013, 106, 311-321. [CrossRef] [PubMed]

4. Chan, L.M.; Brown, J.L.; Yoder, A.D. Integrating Statistical Genetic and Geospatial Methods Brings New Power to Phylogeography. Mol. Phylogenet. Evol. 2011, 59, 523-537. [CrossRef]

5. Constantino, R. The Pest Termites of South America: Taxonomy, Distribution and Status. J. Appl. Entomol. 2002, 126, 355-365. [CrossRef]

6. Hapukotuwa, N.K.; Grace, J.K. Preferences of Coptotermes formosanus Shiraki and Coptotermes gestroi (Wasmann) (Blattodea: Rhinotermitidae) Among Three Commercial Wood Species. Insects 2011, 2, 499-508. [CrossRef] [PubMed]

7. Lee, C.-Y. Control of Foraging Colonies of Subterranean Termites, Coptotermes travians (Isoptera: Rhinotermitidae) in Malaysia Using Hexaflumuron Baits. Sociobiology 2002, 39, 411-416.

8. Kirton, Y.P.; Kirton, L.G. A Note on a Survey of Termite Attack in Bahau Conifer Plantation. J. Trop. For. Sci. 1998, $10,564-567$.

9. Jones, D.T.; Prasetyo, A.H. A Survey of the Termites (Insecta: Isoptera) of Tabalong District, South Kalimantan, Indonesia. Raffles Bull. Zool. 2002, 50, 117-128.

10. Chouvenc, T.; Li, H.-F.; Austin, J.; Bordereau, C.; Bourguignon, T.; Cameron, S.L.; Cancello, E.M.; Constantino, R.; Costa-Leonardo, A.M.; Eggleton, P.; et al. Revisiting Coptotermes (Isoptera: Rhinotermitidae): A Global Taxonomic Road Map for Species Validity and Distribution of an Economically Important Subterranean Termite Genus. Syst. Entomol. 2016, 41, 299-306. [CrossRef]

11. Lee, C.-Y. Subterranean Termite Pests and Their Control in the Urban Environment in Malaysia. Sociobiology 2002, 40, 3-10.

12. Rahman, H.; Fernandez, K.; Arumugam, N. Termites Infesting Malaysian Forests: Case Study from Bornean Forest, Sabah, Malaysia. In Termites and Sustainable Management: Volume 2-Economic Losses and Management; Khan, M.A., Ahmad, W., Eds.; Springer International Publishing: Cham, Switzerland, 2018; pp. 97-118. [CrossRef]

13. Gray, B.; Buchter, J. Termite Eradication in Araucaria Plantations in New Guinea. Commonw. For. Rev. 1969, $48,201-207$.

14. Lemmens, R.H.M.J.; Soerianegara, I.; Wong, W.C. Plant Resources of South-East Asia. No. 5(2). Timber Trees: Minor Commercial Timbers; Backhuys Publisher: Leiden, The Netherlands, 1995; Volume 5, p. 651.

15. Wikantyoso, B.; Himmi, S.K.; Yusuf, S. A Case Report of Termite Attack on Mango Fruit: Plasticity in Feeding? In Proceedings of the National Seminar of Entomological Society of Indonesia, Sumedang, Indonesia, 10 October 2019; pp. 1-6.

16. Bourguignon, T.; Roisin, Y. Revision of the Termite Family Rhinotermitidae (Isoptera) in New Guinea. ZooKeys 2011, 148, 55-103. [CrossRef]

17. Li, H.-F.; Kanzaki, N.; Su, N.-Y. Redescription of the Drywood Termite Incisitermes inamurae (Isoptera: Kalotermitidae) from Southern Taiwan. Ann. Entomol. Soc. Am. 2009, 102, 759-765. [CrossRef]

18. Marquina, D.; Buczek, M.; Ronquist, F.; Łukasik, P. The Effect of Ethanol Concentration on the Morphological and Molecular Preservation of Insects for Biodiversity Studies. bioRxiv 2020. [CrossRef] 
19. Koshikawa, S.; Matsumoto, T.; Miura, T. Morphometric Changes During Soldier Differentiation of the Damp-wood Termite Hodotermopsis japonica (Isoptera, Termopsidae). Insectes Sociaux 2002, 49, 245-250. [CrossRef]

20. Kaji, T.; Keiler, J.; Bourguignon, T.; Miura, T. Functional Transformation Series and the Evolutionary Origin of Novel Forms: Evidence from a Remarkable Termite Defensive Organ. Evol. Dev. 2016, 18, 78-88. [CrossRef] [PubMed]

21. Hanh, T.V.; Hien, N.T.; Yen, N.; Hu-Án, T.T. Applying Molecular Technology to Identify Termite Species of the Genus Coptotermes in the Hanoi Old Quarter. In Proceedings of the 10th Pacific-Termite Research Group Conference, Kuala Lumpur, Malaysia, 26-28 February 2014. S1-1.

22. Kirton, L.G.; Brown, V.K. The Taxonomic Status of Pest Species of Coptotermes in Southeast Asia: Resolving the Paradox in the Pest Status of the Termites, Coptotermes gestroi, C. havilandi and C. travians (Isoptera: Rhinotermitidae). Sociobiology 2003, 42, 43-63.

23. Ahmad, M. Key to the Indomalayan Termites. Biologia 1958, 4, 1-193.

24. Roonwal, M.L.; Chhotani, O.B. Termite Fauna of Assam Region, Eastern India; Zoological Survey of India: Calcutta, India, 1962; Volume 28, p. 406.

25. Roonwal, M.L.; Maiti, P.K. Termite from Indonesia Including West Irian. Treubia 1966, 27, 63-140.

26. Roonwal, M.L.; Chhotani, O.B. Fauna of India; the Director of Zoological Survey of India, Ed.; Zoological Survey of India: Calcutta, India, 1989; Volume 1, p. 665.

27. Tho, Y.P. Termites of Peninsular Malaysia. Malay. For. Rec. 1992, 36, 1-224.

28. Kushwaha, K.S. External Morphology of the Termite, Odontotermes obesus (Rambur) (Isoptera: Termitidae). Part 3. Chaetotaxy of the Soldier, Worker and Alate Castes. Rec. Indian Mus. 1960, 58, 71-114.

29. Kushwaha, K.S. Chaetotaxy of the Termite, Odontotermes assmuthi Holmgren (Isoptera: Termitidae). Proc. Indian Acad. Sci. Sect. B 1961, 54, 130-137. [CrossRef]

30. Takematsu, Y. The Genus Reticulitermes (Isoptera: Rhinotermitidae) in Japan, with Description of a New Species. Entomol. Sci. 1999, 2, 231-243.

31. Constantino, R. Key to the Soldiers of South American Heterotermes with a New Species from Brazil (Isoptera: Rhinotermitidae). Insect Syst. Evol. 2000, 31, 463-472. [CrossRef]

32. Kushwaha, K.S. Taxonomic Differentiation in Three Species of Odontotermes (Isoptera:Termitidae) as Based on Chaetotaxy. In Termites in the Humid Tropics: Proceedings of the New Delhi Symposium; Sharma, S.K., Ed.; UNESCO: Delhi, India, $1962 ;$ pp. 52-55.

33. Gathorne-Hardy, F.J.; Collins, N.; Buxton, R.D.; Eggleton, P. A Faunistic Review of the Termites (Insecta: Isoptera) of Sulawesi, Including an Updated Checklist of the Species. Malay. Nat. J. 2000, 54, 347-353.

34. Gathorne-Hardy, F.J.; Jones, D.T.; Mawdsley, N.A. The Recolonization of the Krakatau Islands by Termites (Isoptera), and Their Biogeographical Origins. Biol. J. Linn. Soc. 2000, 71, 251-267. [CrossRef]

35. Krishna, K.; Grimaldi, D.A.; Krishna, V.; Engel, M.S. Treatise on the Isoptera of the World. Bull. Am. Mus. Nat. Hist. 2013, 377, 627-971.

36. Mutanen, M.; Pretorius, E. Subjective Visual Evaluation vs. Traditional and Geometric Morphometrics in Species Delimitation: A Comparison of Moth Genitalia. Syst. Entomol. 2007, 32, 371-386. [CrossRef]

37. Jost, J. Relations and Dependencies between Morphological Characters. Theory Biosci. 2017, 136, 69-83. [CrossRef] [PubMed]

38. Seilacher, A.; Gishlick, A.D. Morphodynamics; CRC Press: Boca Raton, FL, USA, 2014; p. 551. [CrossRef]

39. Añez, N.; Valenta, D.; Cazorla, D.; Quicke, D.; Feliciangeli, M. Multivariate Analysis To Discriminate Species of Phlebotomine Sand Flies (Diptera: Psychodidae): Lutzomyia townsendi, L. spinicrassa, and L. youngi. J. Med. Entomol. 1997, 34, 312-316. [CrossRef]

40. Yeap, B.-K.; Dugal, F.M.; Othman1, A.S.; Lee, C.-Y. Genetic Relationship Between Coptotermes heimi and Coptotermes gestroi (Isoptera: Rhinotermitidae). Sociobiology 2010, 56, 291-311.

41. Atmaja, V.; Hamidy, A.; Arisuryanti, T.; Matsui, M.; Smith, E. A New Species of Microhyla (Anura: Microhylidae) from Sumatra, Indonesia. Treubia 2019, 45, 25-46. [CrossRef]

42. Tatsuta, H.; Takahashi, K.H.; Sakamaki, Y. Geometric Morphometrics in Entomology: Basics and Applications. Entomol. Sci. 2018, 21, 164-184. [CrossRef]

43. Cooke, S.B.; Terhune, C.E. Form, Function, and Geometric Morphometrics. Anat. Rec. 2015, 298, 5-28. [CrossRef] [PubMed]

44. Klingenberg, C.P. MorphoJ: An Integrated Software Package for Geometric Morphometrics. Mol. Ecol. Resour. 2011, 11, 353-357. [CrossRef] [PubMed]

45. Klingenberg, C.P.; Barluenga, M.; Meyer, A. Shape Analysis of Symmetric Structures: Quantifying Variation Among Individuals and Asymmetry. Evolution 2002, 56, 1909-1920. [CrossRef]

46. James Rohlf, F.; Marcus, L.F. A Revolution Morphometrics. Trends Ecol. Evol. 1993, 8, 129-132. [CrossRef]

47. Savriama, Y. A Step-by-Step Guide for Geometric Morphometrics of Floral Symmetry. Front Plant Sci 2018, 9, 1433. [CrossRef]

48. Lo, N.; Kitade, O.; Miura, T.; Constantino, R.; Matsumoto, T. Molecular Phylogeny of the Rhinotermitidae. Insectes Sociaux 2004, 51,365-371. [CrossRef]

49. Yeap, B.-K.; Othman, A.S.; Lee, V.S.; Lee, C.-Y. Genetic Relationship Between Coptotermes gestroi and Coptotermes vastator (Isoptera: Rhinotermitidae). J. Econ. Entomol. 2007, 100, 467-474. [CrossRef]

50. Hill, G.F. Termites (Isoptera) from the Australian Region; Daw, H.E., Ed.; Government Printer: Melbourne, Australia, 1942.

51. Ahmad, M. Termites (Isoptera) of Thailand; Bulletin of the American Museum of National History: New York, NY, USA, 1965; Volume 131.

52. Thapa, R.S. Termites of Sabah (East Malaysia); Forestry Department: Sabah, Malaysia, 1982. 
53. Maiti, P.K. A Taxonomic Monograph on the World Species of Termites of the Family Rhinotermitidae (Isoptera: Insecta). In Memoirs of the Zoological Survey of India; Zoological Survey of India: Calcutta, India, 2006; Volume 20, p. 272.

54. Parés-Casanova, P.M.; Salamanca-Carreño, A.; Crosby-Granados, R.A.; Bentez-Molano, J. A Comparison of Traditional and Geometric Morphometric Techniques for the Study of Basicranial Morphology in Horses: A Case Study of the Araucanian Horse from Colombia. Animals 2020, 10, 118. [CrossRef]

55. Syaukani. A Guide to The Nasus Termites (Nasutitermitinae, Termitidae) of Kerinci Seblat Nasional Park, Sumatra; Yamane, S., Ed.; Nagao Natural Environment Foundation: Tokyo, Japan, 2010; p. 139.

56. Li, H.-F.; Lan, Y.-C.; Su, N.-Y. Redescription of Prorhinotermes japonicus (Isoptera: Rhinotermitidae) From Taiwan. Ann. Entomol. Soc. Am. 2011, 104, 878-885. [CrossRef]

57. Takematsu, Y.; Vongkulang, C. A Taxonomic Review of the Rhinotermitidae (Isoptera) of Thailand. J. Nat. Hist. 2012, 46, 1079-1109. [CrossRef]

58. Lee, W.; Choi, D.-S.; Ji, J.-Y.; Kim, N.; Han, J.M.; Park, S.-H.; Lee, S.; Seo, M.S.; Hwang, W.-J.; Forschler, B.T.; et al. A New Record of Reticulitermes kanmonensis Takematsu, 1999 (Isoptera: Rhinotermitidae) from Korea. J. Asia Pac. Entomol. 2015, 18, 351-359. [CrossRef]

59. Smith, D.K. A Morphometric Analysis of Allosaurus. J. Vertebr. Paleontol. 1998, 18, 126-142. [CrossRef]

60. Marramà, G.; Kriwet, J. Principal Component and Discriminant Analyses as Powerful Tools to Support Taxonomic Identification and Their Use for Functional and Phylogenetic Signal Detection of Isolated Fossil Shark Teeth. PLoS ONE 2017, 12, e0188806. [CrossRef] [PubMed]

61. Rohlf, F.J. Tps Utility Program, 1.78; Ecology \& Evolution and Anthropology, Stony Brook University: New York, NY, USA, 2019.

62. Bookstein, F.L. Size and Shape Spaces for Landmark Data in Two Dimensions. Stat. Sci. 1986, 1, 181-222. [CrossRef]

63. Bookstein, F.L. Landmark Methods for Forms Without Landmarks: Morphometrics of Group Differences in Outline Shape. Med. Image Anal. 1997, 1, 225-243. [CrossRef]

64. Zelditch, M.L.; Swiderski, D.L.; Sheets, H.D.; Fink, W.L. Beyond Two-dimensional Configurations of Landmarks. In Geometric Morphometrics for Biologists; Zelditch, M.L., Swiderski, D.L., Sheets, H.D., Fink, W.L., Eds.; Academic Press: San Diego, CA, USA, 2004; pp. 385-407. [CrossRef]

65. Rohlf, F.J. TpsDig2, 2.31; Ecology \& Evolution and Anthropology, Stony Brook University: New York, NY, USA, 2017.

66. Pietrusewsky, M.; Lauer, A.; Tsang, C.H.; Li, K.T.; Douglas, M.T. A Biodistance Analysis of Mandibles From Taiwan, Asia, and the Pacific: A Search for Polynesian Origins. In Biological Distance Analysis; Pilloud, M.A., Hefner, J.T., Eds.; Academic Press: San Diego, CA, USA, 2016; pp. 447-461. [CrossRef]

67. Ramos, S.D.S.; Rickard Liow, S.J. Discriminant Function Analysis. In The Encyclopedia of Applied Linguistics; Chapelle, C.A., Ed.; John Wiley \& Sons: Chichester, UK, 2012. [CrossRef]

68. Klingenberg, C.P. Size, Shape, and Form: Concepts of Allometry in Geometric Morphometrics. Dev. Genes Evol. 2016, 226 , 113-137. [CrossRef]

69. Kambhampati, S.; Smith, P.T. PCR Primers for the Amplification of Four Insect Mitochondrial Gene Fragments. Insect Mol. Biol. 1995, 4, 233-236. [CrossRef] [PubMed]

70. Hall, T.A. BioEdit: A User-Friendly Biological Sequence Alignment Editor and Analysis Program for Windows 95/98/NT. Nucleic Acids Symp. Ser. 1999, 41, 95-98.

71. Thompson, J.D.; Gibson, T.J.; Plewniak, F.; Jeanmougin, F.; Higgins, D.G. The CLUSTAL_X Windows Interface: Flexible Strategies for Multiple Sequence Alignment Aided by Quality Analysis Tools. Nucleic Acids Res. 1997, 25, 4876-4882. [CrossRef] [PubMed]

72. Kimura, M. A Simple Method for Estimating Evolutionary Rates of Base Substitutions Through Comparative Studies of Nucleotide Sequences. J. Mol. Evol. 1980, 16, 111-120. [CrossRef]

73. Kumar, S.; Stecher, G.; Tamura, K. MEGA7: Molecular Evolutionary Genetics Analysis Version 7.0 for Bigger Datasets. Mol. Biol. Evol. 2016, 33, 1870-1874. [CrossRef] [PubMed]

74. Tanabe, A.S. Kakusan: A Computer Program to Automate the Selection of a Nucleotide Substitution Model and the Configuration of a Mixed Model on Multilocus Data. Mol. Ecol. Notes 2007, 7, 962-964. [CrossRef]

75. Ronquist, F.; Teslenko, M.; van der Mark, P.; Ayres, D.L.; Darling, A.; Höhna, S.; Larget, B.; Liu, L.; Suchard, M.A.; Huelsenbeck, J.P. MrBayes 3.2: Efficient Bayesian Phylogenetic Inference and Model Choice Across a Large Model Space. Syst. Biol. 2012, 61, 539-542. [CrossRef]

76. Tamura, K.; Peterson, D.; Peterson, N.; Stecher, G.; Nei, M.; Kumar, S. MEGA5: Molecular Evolutionary Genetics Analysis Using Maximum Likelihood, Evolutionary Distance, And Maximum Parsimony Methods. Mol. Biol. Evol. 2011, 28, 2731-2739. [CrossRef]

77. Hillis, D.M.; Bull, J.J. An Empirical Test of Bootstrapping as a Method for Assessing Confidence in Phylogenetic Analysis. Syst. Biol. 1993, 42, 182-192. [CrossRef]

78. Huelsenbeck, J.P.; Rannala, B. Frequentist Properties of Bayesian Posterior Probabilities of Phylogenetic Trees Under Simple and Complex Substitution Models. Syst. Biol. 2004, 53, 904-913. [CrossRef] [PubMed]

79. Leache, A.; Reeder, T. Molecular Systematics of the Eastern Fence Lizard (Sceloporus undulatus): A Comparison of Parsimony, Likelihood, and Bayesian Approaches. Syst. Biol. 2002, 51, 44-68. [CrossRef]

80. Huelsenbeck, J.P.; Ronquist, F. MRBAYES: Bayesian Inference of Phylogenetic Trees. Bioinformatics 2001, 17, 754-755. [CrossRef] [PubMed] 
81. Drake, A.G.; Klingenberg, C.P. The Pace of Morphological Change: Historical Transformation of Skull Shape in St Bernard Dogs. Proc. R. Soc. B Biol. Sci. 2008, 275, 71-76. [CrossRef]

82. Tokuda, G.; Isagawa, H.; Sugio, K. The Complete Mitogenome of the Formosan Termite, Coptotermes formosanus Shiraki. Insectes Sociaux 2012, 59, 17-24. [CrossRef]

83. Bourguignon, T.; Lo, N.; Šobotník, J.; Sillam-Dussès, D.; Roisin, Y.; Evans, T.A. Oceanic Dispersal, Vicariance and Human Introduction Shaped the Modern Distribution of the Termites Reticulitermes, Heterotermes and Coptotermes. Proc. R. Soc. B Biol. Sci. 2016, 283, 20160179. [CrossRef]

84. Inward, D.J.G.; Vogler, A.P.; Eggleton, P. A Comprehensive Phylogenetic Analysis of Termites (Isoptera) Illuminates Key Aspects of Their Evolutionary Biology. Mol. Phylogenet. Evol. 2007, 44, 953-967. [CrossRef] [PubMed]

85. Deligne, J.; Quennedey, A.; Blum, M.S. The Enemies and Defense Mechanisms of Termites. In Social Insects; Hermann, H.R., Ed.; Academic Press: London, UK, 1981; pp. 1-76. [CrossRef]

86. Wasmann, E. Viaggio di Leonardo Fea in Birmania e Regioni Vicine, LXXII: Neue Termitophilen und Termiten Aus Indien. Ann. Mus. Civ. Stor. Nat. Genova 1896, 16, 613-630.

87. Scheffrahn, R.; Carrijo, T.; Krecek, J.; Su, N.-Y.; Szalanski, A.; Austin, J.; Chase, J.; Mangold, J. A Single Endemic and Three Exotic Species of the Termite Genus Coptotermes (Isoptera, Rhinotermitidae) in the New World. Arthropod Syst. Phylogeny 2015, 73, 333-348.

88. Scheffrahn, R.; Su, N.-Y. Asian Subterranean Termite, Coptotermes gestroi (=havilandi) (Wasmann) (Insecta: Blattodea: Rhinotermitidae). Available online: https:/ / edis.ifas.ufl.edu/publication/IN285 (accessed on 18 May 2021).

89. Li, H.F.; Yang, R.L.; Su, N.Y. Interspecific Competition and Territory Defense Mechanisms of Coptotermes formosanus and Coptotermes gestroi (Isoptera: Rhinotermitidae). Environ. Entomol. 2010, 39, 1601-1607. [CrossRef]

90. Li, H.-F.; Ye, W.; Su, N.-Y.; Kanzaki, N. Phylogeography of Coptotermes gestroi and Coptotermes formosanus (Isoptera: Rhinotermitidae) in Taiwan. Ann. Entomol. Soc. Am. 2009, 102, 684-693. [CrossRef]

91. Chouvenc, T.; Basille, M.; Li, H.F.; Su, N.Y. Developmental Instability in Incipient Colonies of Social Insects. PLoS ONE 2014, 9, e113949. [CrossRef]

92. Quennedey, A.; Deligne, J. L'arme Frontale des Soldats de Termites. I. Rhinotermitidae. Insectes Sociaux 1975, $22,243-267$. [CrossRef]

93. Chhotani, O.B. Termite Pest of Agriculture in the Indian Region and Their Control; Zoological Survey of India: Calcutta, India, 1980; Volume 4, pp. 29-33.

94. Chen, G.-Y.; Ke, Y.-L.; Liang, W.-R.; Li, H.-F. Redescription of Formosan Subterranean Termite, Coptotermes formosanus (Blattodea: Rhinotermitidae), with Three New Synonyms from China. Acta Entomol. Musei Natl. Pragae 2020, 60, 599-608. [CrossRef]

95. Kalshoven, L.G.E. Observations on Coptotermes havilandi Holmgr. (javanicus Kemn.) (Isoptera). Beaufortia 1962, 9, $121-137$.

96. Jamil, N.; Singham, V.; Wan Ismail, W.N. Morphometric Variation and Genetic Relationship of Coptotermes spp. (Blattodea: Rhinotermitidae) in Sarawak, Malaysia. Malays. Appl. Biol. J. 2018, 47, 113-125.

97. Matsuura, K. Colony-Level Stabilization of Soldier Head Width for Head-Plug Defense in the Termite Reticulitermes speratus (Isoptera: Rhinotermitidae). Behav. Ecol. Sociobiol. 2002, 51, 172-179. [CrossRef]

98. Hao, Y.-N.; Sun, Y.-X.; Liu, C.-Z. Functional Morphology of Antennae and Sensilla of Hippodamia variegata (Coleoptera: Coccinellidae). PLoS ONE 2020, 15, e0237452. [CrossRef] [PubMed]

99. Parashar, B.; Chauhan, R.; Prakash, S.; Rao, K. Mechanotactile and Olfactory Antennal Sensilla in Four Species of Female Tabanids (Diptera). Ital. J. Zool. 1994, 61, 121-128. [CrossRef]

100. Liu, Z.; Hua, B.-Z.; Liu, L. Ultrastructure of the Sensilla on Larval Antennae and Mouthparts in the Peach Fruit Moth, Carposina sasakii Matsumura (Lepidoptera: Carposinidae). Micron 2011, 42, 478-483. [CrossRef]

101. Nowińska, A.; Brożek, J. Morphological Study of the Antennal Sensilla in Gerromorpha (Insecta: Hemiptera: Heteroptera). Zoomorphology 2017, 136, 327-347. [CrossRef]

102. Hallberg, E.; Hansson, B.S. Arthropod Sensilla: Morphology and Phylogenetic Considerations. Microsc. Res. Tech. 1999, 47, 428-439. [CrossRef]

103. Yanagawa, A.; Shimizu, S.; Noma, K.; Nishikawa, M.; Kazumasa, O.; Yokohari, F. Classification and Distribution of Antennal Sensilla of the Termite Coptotermes formosanus (Isoptera: Rhinotermitidae). Sociobiology 2009, 54, 327-349.

104. Oberst, S.; Bann, G.; Lai, J.C.S.; Evans, T.A. Cryptic Termites Avoid Predatory Ants by Eavesdropping on Vibrational Cues from Their Footsteps. Ecol. Lett. 2017, 20, 212-221. [CrossRef]

105. Evans, T.A.; Inta, R.; Lai, J.C.; Prueger, S.; Foo, N.W.; Fu, E.W.E.; Lenz, M. Termites Eavesdrop to Avoid Competitors. Proc. R. Soc. B Biol. Sci. 2009, 276, 4035-4041. [CrossRef] [PubMed]

106. Romiti, F.; Redolfi DeZan, L.; Piras, P.; Carpaneto, G.M. Shape Variation of Mandible and Head in Lucanus cervus (Coleoptera: Lucanidae): A Comparison of Morphometric Approaches. Biol. J. Linn. Soc. 2016, 120, 1-16. [CrossRef]

107. David, S.; Funken, J.; Potthast, W.; Blanke, A. Musculoskeletal Modelling Under an Evolutionary Perspective: Deciphering the Role of Single Muscle Regions in Closely Related Insects. J. R. Soc. Interface 2016, 13. [CrossRef] [PubMed]

108. Blanke, A.; Pinheiro, M.; Watson, P.J.; Fagan, M.J. A Biomechanical Analysis of Prognathous and Orthognathous Insect Head Capsules: Evidence for a Many-to-one Mapping of Form to Function. J. Evol. Biol. 2018, 31, 665-674. [CrossRef] [PubMed]

109. Weihmann, T.; Wipfler, B. The Generalized Feeding Apparatus of Cockroaches: A Model for Biting and Chewing Insects; Springer: Cham, Switzerland, 2019; pp. 203-262. [CrossRef] 
110. Wipfler, B.; Weißing, K.; Klass, K.-D.; Weihmann, T. The Cephalic Morphology of the American Cockroach Periplaneta americana (Blattodea). Arthropod Syst. Phylogeny 2016, 74, 267-297.

111. Mizuno, T.; Kojima, Y. A Blindsnake that Decapitates Its Termite Prey. J. Zool. 2015, 297, 220-224. [CrossRef]

112. Arif, A.; Putri, G.; Lestari, P.I.; Widawati; Nurqalbi, M.; Saira, A. Diversity of Termite Rhinotermitidae (Isoptera, Insecta) in Educational Forest of Hasanuddin University. Perennial 2020, 16, 59-67. [CrossRef]

113. Arif, A.; Putri, G.; Muin, M. Hazard Mapping of Subterranean Termite Attacks in Makassar City, South Sulawesi, Indonesia. Insects 2019, 11, 31. [CrossRef]

114. Retmadhona, I.Y. Species Diversity, Spatial Distribution, and Intensity of Soil Termite Attack on Acacia Crassicarpa Stand on Peatlands; Institut Pertanian Bogor: Bogor, Indonesia, 2017.

115. Subekti, N. Population Characteristics of Subterranean Termite Coptotermes spp (Blattodea: Rhinotermitidae) and the Impact of the Attack. Biosaintifika J. Biol. Biol. Educ. 2010, 2. [CrossRef]

116. Arinana, A.; Aldina, R.; Nandika, D.; Rauf, A.; Harahap, I.S.; Sumertajaya, I.M.; Bahtiar, E.T. Termite Diversity in Urban Landscape, South Jakarta, Indonesia. Insects 2016, 7, 20. [CrossRef]

117. Indrayani, Y. Short Communication: Diversity and distribution of termites in buildings in Pontianak City, West Kalimantan, Indonesia. Biodivers. J. Biol. Divers. 2017, 18. [CrossRef]

118. Gallego-Abenza, M.; Mathevon, N.; Wheatcroft, D. Experience Modulates an Insect's Response to Anthropogenic Noise. Behav. Ecol. 2019, 31, 90-96. [CrossRef] [PubMed]

119. Tricot, M.-C.C.; Cammaerts, R. Impact of Environmental Noise on Insects' Physiology and Ethology-A Study on Ants as Models. Bioelectromagnetics 2018, 3, 1-8.

120. Bowen, A.E.; Gurule-Small, G.A.; Tinghitella, R.M. Anthropogenic Noise Reduces Male Reproductive Investment in an Acoustically Signaling Insect. Behav. Ecol. Sociobiol. 2020, 74, 103. [CrossRef]

121. Dinakaran, S.; Anbalagan, S. Anthropogenic Impacts on Aquatic Insects in Six Streams of South Western Ghats. J. Insect Sci. 2007, 7. [CrossRef] 